\title{
Modelling hygrothermal conditions of unsaturated substrate and drainage layers for the thermal resistance assessment of green roof: effect of coarse recycled materials
}

\author{
Mostafa Kazemi ${ }^{1 *}$, Luc Courard ${ }^{2}$
}

\section{Corresponding author*}

1- Ph.D. Candidate, GeMMe Building Materials, Urban and Environmental Engineering (UEE), University of Liege, 4000 Liège, Belgium, E-mail: mostafa.kazemi@uliege.be

2- Full Professor, GeMMe Building Materials, Urban and Environmental Engineering (UEE), University of Liege, 4000 Liège, Belgium, Email: luc.courard@uliege.be

\begin{abstract}
Alternative materials exist for green roof layers: secondary resources like coarse or fine recycled aggregates may be used as a substitute to natural materials. For using these new types of materials, it is needed to assess their heat resistance which is performed according to ISO 9869-1 standard. Moreover, the initial hygrothermal conditions of unsaturated substrate and drainage layers have also to be modelled and assessed for optimizing the layers' thickness. In this study, the green roofs with unsaturated substrate and drainage layers incorporating coarse recycled materials were tested and assessed. The hygrothermal conditions of unsaturated substrate and drainage layers were simulated using WUFI software. A small difference (4.2\%) was observed between the Rc-value of the green roofs with and without coarse recycled materials, confirming that these materials provided a sufficient thermal resistance, similar to soil particles for the substrate layer. Considering a constant thickness for the substrate layer $(15 \mathrm{~cm})$, a 6-cm drainage layer with coarse aggregates was considered as the optimum design for green roof systems. Besides, 18-cm unsaturated substrate layer was the optimum design when the drainage layer' thickness was considered constant $(5 \mathrm{~cm})$. The 6 - $\mathrm{cm}$ drainage layer and $18-\mathrm{cm}$ unsaturated substrate layer were definitely the best design for the roofing systems with the simultaneous change in the substrate and drainage layers' thickness.
\end{abstract}

Keywords: Thermal transfer modelling; parametric study; substrate; drainage layer; coarse recycled materials.

\section{Introduction}

The rapid urbanization growth in the developing world has raised a series of intractable challenges over the environment with the overuse of natural resources to provide the internal thermal comfort in buildings, accounting for nearly $40 \%$ of the worldwide energy consumption [14]. The energy demand of dwelling houses in urban regions is highly dependent on the building envelope components such as exterior walls and roofs [4-9]. Specially for poorly insulated rooftops, replacing the conventional flat roofs with the extensive green roof has drawn the attention of researchers [9-13]. As a nature-based solution, the extensive green roof has lower weight and 
shallower depth compared to the intensive green roof and the former is able to play a fundamental role in improving the energy efficiency of houses and rooftops $[7,14,15]$.

From the top of the green roof to its bottom, its layers are composed of vegetation, substrate, filter, drainage and insulation layers [16,17]. Since the green roof's thermal resistance was found to be dependent on the materials' physical characteristics used for its layers including the substrate and drainage layers [18], the influence of different types of materials over the green roof layers' performance has been highly regarded by researchers [18-20]. For instance, the polyethylene modular panel and natural gravel have been used for the drainage layer [21-25]. The influence of the aforementioned materials over the green roof systems' performance was compared to each other by Wanielista and Hardin [26]. As a result, the water flowed away from the bottom of green roof system had nearly the same quality either with the natural gravel aggregate or with the polyethylene modular panel as the drainage layer. A study by Parizotto and Lamberts [27] demonstrated that the diffusion characteristics of substrate and the drainage layer of pebble and gravel aggregates improved the heat retention capacity of green roof systems by generating the thermal mass at the rooftops, contributing to increasing the heat transfer resistance of green roof layers and subsequently decreasing the diurnal temperature change.

Due to the dependence of the heat flux on the water content of substrate and drainage layers, the hygrothermal performances of green roof layers has already been investigated by researchers [18,28-32]. Yang and Wang [33] showed that the thermal performance of green roof systems was highly dependent on the hygrothermal properties of the substrate layer. Ouldboukhitine et al. [28] showed that the thermal properties of the soil effectively influenced the energy balance at the substrate surface. Besides, the internal thermal comfort was improved by replacing the classical roof (concrete slab) with the green roof due to lower temperature of soil medium and better reflection of solar radiation from the substrate surface. A study by Sun et al. [34] showed that the thermal performance of the green roof was noticeably influenced by the substrate layers' moisture and the incoming solar radiation, while the effect of the relative humidity on the thermal resistance of green roof layers was not so much. He et al. [35] showed that the soil water content remarkably affected the evapotranspiration phenomenon and the green roof's thermal performance was improved by increasing the soil moisture level owing to increasing the evaporated water during the summer period. Vertal' et al. [36] simulated the initial hygrothermal conditions of green roof layers using WUFI software and then they assessed their heat and moisture performance. According to the results, the roof membrane's temperature was affected by the substrate's water content. Moreover, the roof structure's life cycle increased owing to the participation of the substrate's water content for decreasing the membrane temperature as well as the heat flux across the roof. This process prevented overheating in buildings during the summer season. Fabisni et al. [37] demonstrated the thermal properties of substrate and drainage layers was influenced by their water content. As a result, the raining processes increased the substrate's thermal conductivity up to triple. According to a study by $\mathrm{He}$ et al. [38], the green roof decreased the heating and cooling loads of buildings by $6.2 \%$ and $3.6 \%$, respectively. More importantly, increasing the substrate's water content increased the green roof's cooling effect.

The effect of the substrate and drainage layers' thickness on the green roof's thermal performance has gained much attention in recent years. Sun et al. [39] demonstrated that the water content stored on the thin substrate layer evaporated faster, leading to reducing the 
evapotranspiration phenomena at the rooftops and subsequently decreasing the green roof' thermal performance. On the other hand, the use of a thicker substrate layer caused to absorb more moisture by its bottom section, preventing the soil water content from participating the evapotranspiration phenomenon at the rooftop. This process resulted in decreasing the green roof's thermal resistance. In general, the insulation performance of the green roof with a thick substrate layer was better than that of the green roof with a thin substrate layer, even though it was recommended to find the substrate layer's optimum thickness somewhere in the middle. According to a study by He et al. [40], the substrate layer's thickness had a remarkable effect on the heat flux through the green roof system either in winter or in summer. This effect was more in the latter. Besides, increasing the substrate's thickness positively influenced the delay time of heat flux wave and subsequently improved the insulation performance of the green roof; however, the positive effect of the substrate gradually decreased by increasing its thickness, demonstrating the fact that there was a demand to determine an optimum thickness for the substrate layer. The use of rubber crumbs and pozzolana as the drainage layer for green roof systems was tested and assessed by Coma et al. [9,41] in the Mediterranean climate. They showed that increasing the substrate and drainage layers' thickness might compensate low thermal performance of green roof, mainly in the winter season. Subsequently, Kazemi et al. [18,19] simulated the green roof layers including the substrate and the drainage layer of rubber crumbs and pozzolana to assess the layers' thickness effect on the roofing system's thermal performance during the cold and warm periods. Since the WUFI software has been known as one of the best modelling tools to simultaneously stimulate the thermal and moisture transfer processes through green roof layers [36,42,43], it was used by Kazemi et al. [18,19] for modelling the heat and moisture distribution through substrate and drainage layers. Note that the materials' thermal insulation performance has been referred to some indicators, depending on the temperature $[19,44,45]$. Considering this, Kazemi et al. [18,19] assessed the temperature fluctuation within green roof layers to evaluate the roofing systems' thermal resistance. The results demonstrated that increasing the substrate and drainage layers' thickness improved the thermal performance of the roofing system either for winter or for summer period, even though there were no differences between the results of thicker layers. Thus, after the optimization of green roof layers' thickness, the model with 8-cm drainage layer of pozzolana and 10-cm substrate was found to provide a sufficient thermal performance for the roofing systems.

In general, there is a demand for optimizing the green roofs' layers owing to the thermal performance sensitivity of roofing systems to the substrate and drainage layers' thickness $[9,18,19,41]$, because no information was reported by European standards about the optimum thickness of green roof layers, mainly made with different types of materials [46,47]. Additionally, it is questionable whether the use of coarse recycled materials was able to provide a sufficient thermal resistance for the green roof layers, because these materials might affect the hygrothermal conditions of substrate and drainage layers due to their great porosity [48-55]. In light of the foregoing background, in this study, green roofs with the unsaturated substrate incorporating coarse recycled materials and the drainage layer of recycled coarse aggregate were tested and assessed following ISO 9869-1 [56]. Later on, the hygrothermal conditions of unsaturated substrate and drainage layers were translated into the WUFI software and the modelling outputs were compared with green roof specimens' results. Considering the fact that the thermal insulation performance was related to the temperature distribution through the depth of materials $[19,44,45,57]$, the temperature variation within green roof layers was evaluated, where the substrate and drainage 
layers' thickness was changed to achieve an optimum design of green roof systems with an adequate thermal performance.

\section{Methodology}

The reference green roof specimen was composed of the unsaturated substrate without coarse recycled materials and the drainage layer of natural coarse aggregate (Figs. 1(a) and 1(b)): the substrate will act as a support for growing plants and the drainage layer will play an important role beneath the substrate for evacuating water. Besides, the alternative green roof specimen considered unsaturated substrate with recycled tiles and bricks and the drainage layer of recycled coarse aggregate (Figs. 1(c) and 1(d)).

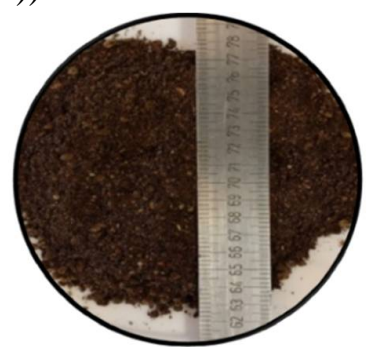

(a)

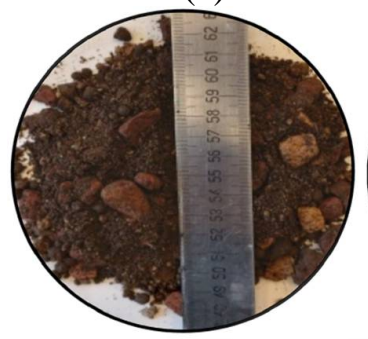

(c)

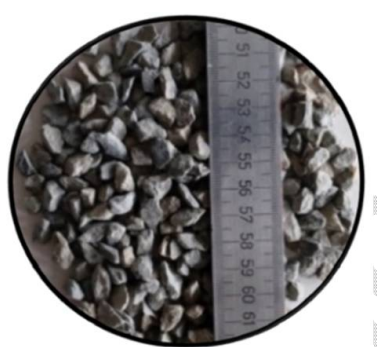

(b)

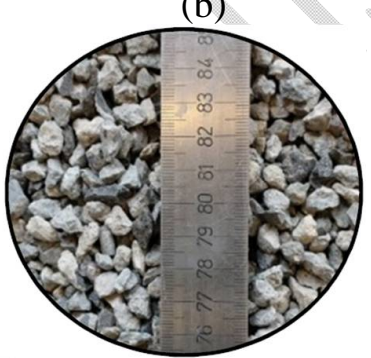

(d)

Fig. 1. The unsaturated substrate without coarse recycled materials (a); the natural coarse aggregate for the drainage layer (b); the unsaturated substrate containing recycled tiles and bricks (c); the recycled concrete coarse aggregate for the drainage layer (d).

The minimum coarse aggregate size is $5 \mathrm{~mm}$ according to EN 12620 [58]. On the other hand, the use of aggregates with very big size is not suitable for the thin depth of the drainage layer (5 $\mathrm{cm})$, Therefore, since the water flux should easily pass through the drainage layer [25,26], the size of $7 \mathrm{~mm}$ was considered for the natural and recycled coarse aggregates.

The total thickness of green roof specimens was $20 \mathrm{~cm}$, where the substrate and drainage layers' thicknesses were considered to be $15 \mathrm{~cm}$ and $5 \mathrm{~cm}$, respectively (Fig. 2(a)). A thin filter layer was used to separate the substrate and drainage layer from each other as shown in Fig. 2(a). The green roof including substrate and drainage layers were put in a $40 \times 40 \times 20 \mathrm{~cm}$ experimental mould and then, they were placed in the centre of thermal transfer measurement device between the cold and hot plates ((Fig. 2(b)), where the surrounding area of the mould was insulated using the polyurethane foam. After that, the mould mentioned above was compressed between the hot and cold plates and their bottom and top were exposed to the temperatures. The thermal conductivity value was automatically measured using the device by means of a sensor installed in the hot plate. 


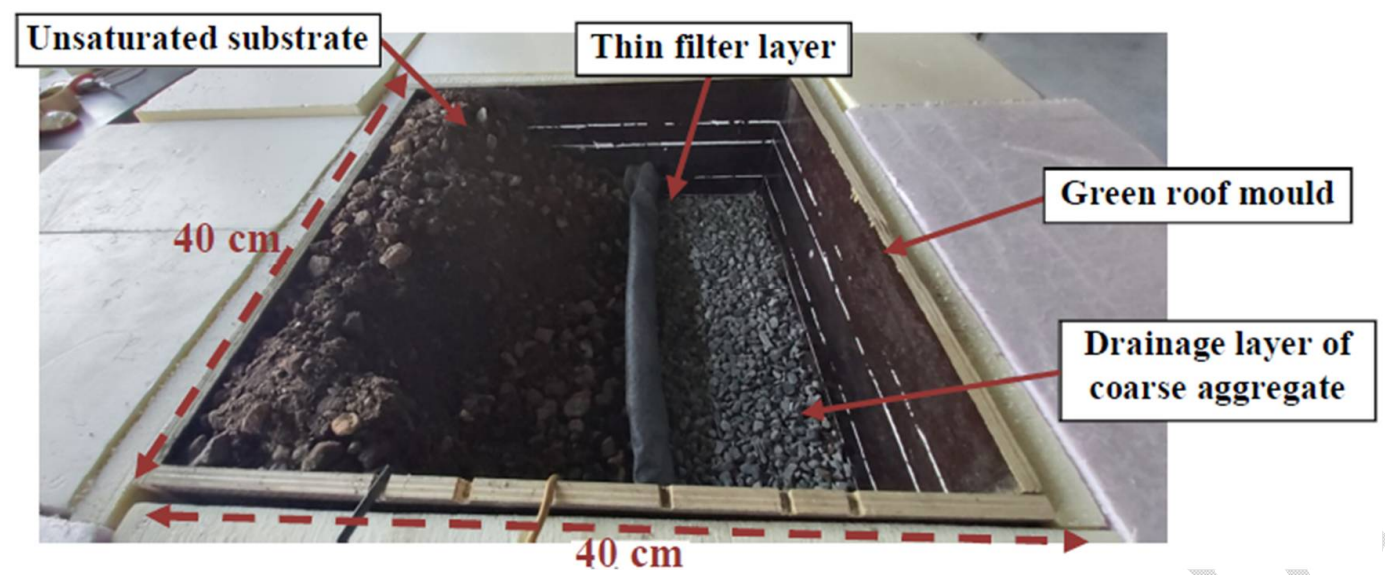

(a)

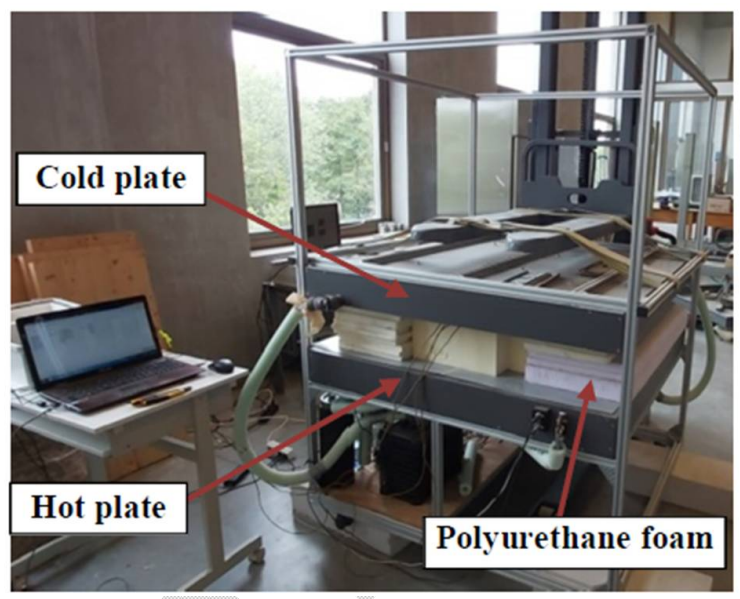

(b)

Fig. 2. Thermal transfer measurement device.

Fig. 3(a) shows a sketch of the control and the proposed green roofs with substrate and drainage layers (NCA5-SC15 and RCA5-SP15). The NCA and RCA were referred to the natural (N) and recycled $(\mathrm{R})$ coarse $(\mathrm{C})$ aggregates $(\mathrm{A})$. Moreover, the substrate layers without and with coarse recycled materials were the control (SC) and the proposed (SP) substrate layers. A cross-sectional view for the $15-\mathrm{cm}$ unsaturated substrate without and with coarse recycled materials (SC15 and SP15) is shown in Fig. 3(b). The unsaturated substrate layers were put in a $40 \times 40 \times 15 \mathrm{~cm}$ experimental mould and they were separately placed in the centre of the thermal transfer measurement device to obtain their thermal resistance. Fig. 3(c) presents the 5-cm natural and recycled coarse aggregates as the drainage layers (NCA5 and RCA5). These layers were separately put in a $40 \times 40 \times 5 \mathrm{~cm}$ experimental mould. After that, they were placed in the centre of the thermal transfer measurement device to assess their thermal performance as the drainage layer. In brief, after the heat resistance measurement of green roof layers following ISO 9869-1 [56], their thermal resistance was compared to each other. 


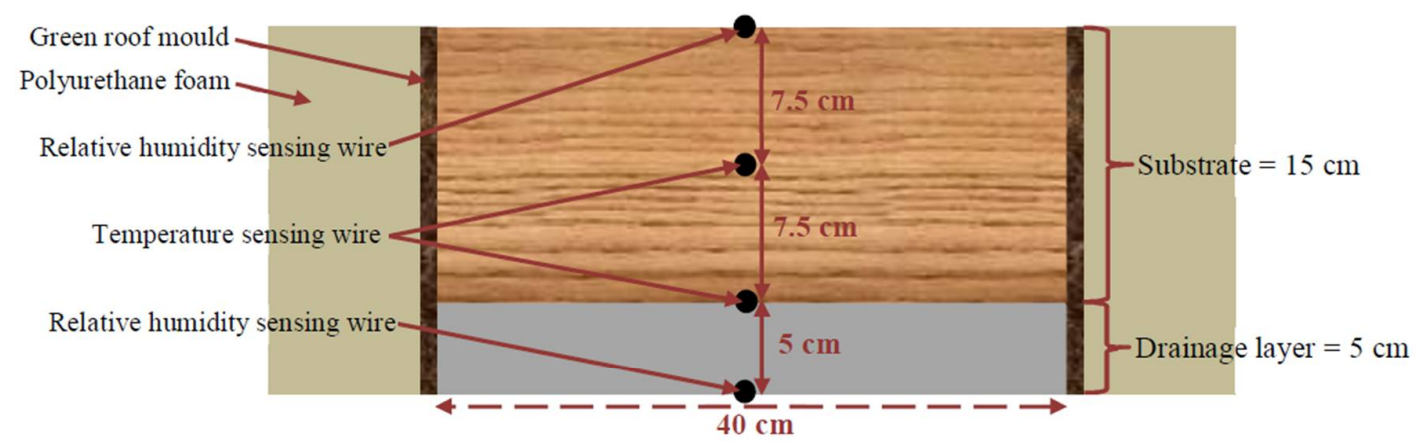

(a)

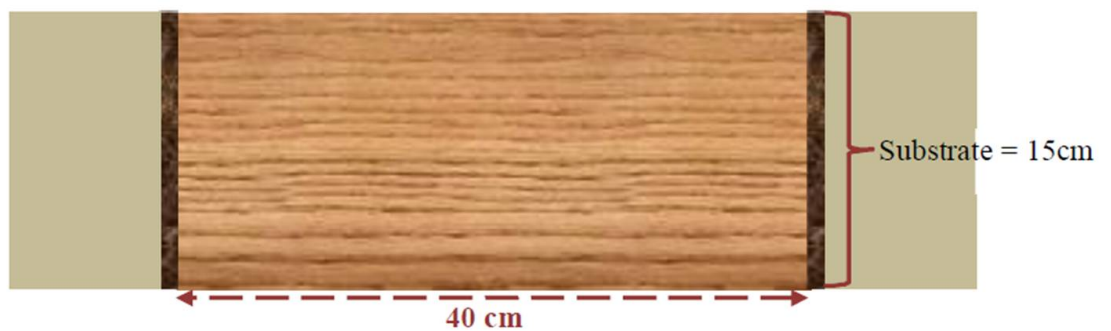

(b)

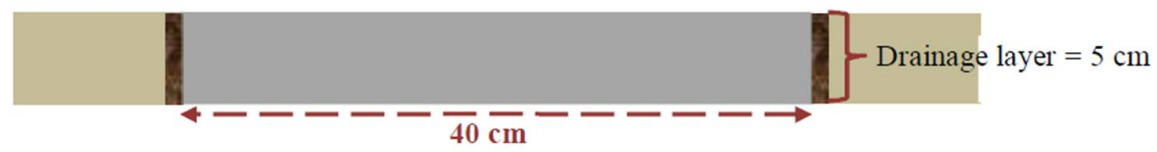

(c)

Fig. 3. Sketchs of green roof layers including the substrate and drainage layers (a); the substrate layer (b); drainage layer (c).

In the next step, the hydrothermal conditions (heat and moisture properties) of the unsaturated substrate layers and coarse aggregates were measured and they were introduced to the WUFI software for modelling the control and the proposed green roof specimens (NCA5-SC15 and RCA5-SP15). Note that the temperatures of the cold and hot plates were applied to the top and the bottom of green roof models. Apart from these temperatures, the air relative humidity at the top and the bottom of the roofing specimens was introduced to the top and bottom of green roof models as well. The air relative humidity was measured using two relative humidity sensing wires installed at the top and the bottom of green roof specimens as shown in Fig. 3(a). Moreover, the temperatures in the middle of substrate and between the substrate and the drainage layer were recorded using two temperature sensing wires (Fig. 3(a)). These two measured temperatures through green roof layers' depth was used to validate the modelling outputs with experimental results.

After the validation of green roof models, since the materials' thermal insulation performance has been related to some indicators depending on the temperature $[19,44,45]$, the temperature distribution within green roof models was evaluated for the optimization of green roof layers. Indeed, by increasing the thickness of the substrate and drainage layers, the optimum design of green roof layers could be determined when no change in the temperature through green roof's depth was observed.

\section{Materials properties and characteristics}




\subsection{Thermal heat transfer (ISO 9869-1)}

The thermal conductivity value $(\lambda)$ was automatically measured by the thermal transfer measurement device (Fig. 2(b)). The lower value of thermal conductivity indicates the higher ability of materials to resist the heat flow [59]. Eq. (1) presents the difference between the top and bottom surfaces of specimen $(\Delta \mathrm{T})$ :

$\Delta \mathrm{T}=\mathrm{T}_{\mathrm{h}}-\mathrm{T}_{\mathrm{c}}$

Where $T_{h}$ and $T_{c}$ are the temperatures in the thermal device's heating and cooling sides, respectively (K).

According to Fourier's law, the density of heat flow rate $(\mathrm{q})$ with the unit of $\mathrm{W} / \mathrm{m}^{2}$ was calculated using Eq. (2):

$\mathrm{q}=\lambda \cdot \frac{\Delta \mathrm{T}}{l}$

Where $l$ is the thickness of green roof layers $(\mathrm{m})$.

Eq. 3 was used to evaluate the convergence of $R_{c}$-value $\left(m^{2} K / W\right)$ using the Average Method given by ISO 9869-1 [56]. The higher amount of R-value demonstrates the more thermal resistance and better insulation performance of materials $[56,60]$.

$\mathrm{R}_{\mathrm{c}}=\frac{\sum_{t=0}^{m} \Delta \mathrm{T}^{t}}{\sum_{t=0}^{m} \mathrm{q}^{t}}$

Where $t$ is the time interval, and $m$ is the minimum required measurement period (h).

To report an acceptable $\mathrm{R}_{\mathrm{c}}$-value based to the Average Method, three main criteria to fulfill and stop the measurement have to be considered as mentioned in the following:

- The measurement period should take at least $72 \mathrm{~h}$.

- The value calculated at the end of the data set should not deviate more than $\pm 5 \%$ from the respective value obtained $24 \mathrm{~h}$ before.

- The resulting value when applying the method to the first $67 \%$ of data should not deviate by more than $\pm 5 \%$ from the respective value when analyzing the last $67 \%$ of the data.

To converge $\mathrm{R}_{\mathrm{c}}$-value using the Average Method given by ISO 9869-1 [56], it has been recommended that the difference between exterior and interior surface temperature should be at least $5-10{ }^{\circ} \mathrm{C}$ when using the Average Method [56,61,62]. Therefore, the top and bottom of green roof specimens were subjected to $16.5^{\circ} \mathrm{C}$ and $23.5{ }^{\circ} \mathrm{C}$, respectively, resulting in the surface temperature difference of $7{ }^{\circ} \mathrm{C}$.

\subsection{Green roof layers' properties}

Table 1 presents the properties of the substrate and coarse aggregates. To model the green roof layers using WUFI software, it was required to obtain the specific capacity of materials in the dry condition. To dry the substrate and coarse aggregates, they were kept in the $40^{\circ} \mathrm{C}$ oven for 7 and 2 days, respectively. After that, their specific heat capacity was measured using the Calorimetric method based on ASTM D4611-16 [63]. This parameter for the dry substrate without and with coarse recycled materials was $880 \mathrm{~J} / \mathrm{kg} \mathrm{K}$ and $810 \mathrm{~J} / \mathrm{kg} \mathrm{K}$, respectively. The specific heat capacity for recycled and natural coarse aggregates was obtained $730 \mathrm{~J} / \mathrm{kg} \mathrm{K}$ and $770 \mathrm{~J} / \mathrm{kg} \mathrm{K}$, respectively. The aforementioned values were nearly within the specific heat capacity ranges given for the dry soil and dried aggregate [64,65]. To consider the moisture content effect of green roof layers on their thermal conductivity values, it was required to measure this parameter for the substrate and 
coarse aggregate layers in both dry and unsaturated conditions according to ISO 9869-1 [56] using the thermal transfer measurement device. Therefore, the relationship between water content of materials and their conductivity could be automatically generated as described in the section 3.2.5.

Table 1. Green roof layers' properties.

\begin{tabular}{|c|c|c|c|c|}
\hline Materials & $\begin{array}{l}\text { Substrate without coarse } \\
\text { recycled materials }\end{array}$ & $\begin{array}{l}\text { Substrate with coarse } \\
\text { recycled materials }\end{array}$ & $\begin{array}{c}\text { Natural coarse } \\
\text { aggregate }\end{array}$ & $\begin{array}{c}\text { Recycled coarse } \\
\text { aggregate }\end{array}$ \\
\hline Bulk density, $\rho_{\mathrm{s}}\left(\mathrm{kg} / \mathrm{m}^{3}\right)$ & 1075.23 & 1000.95 & 1436.56 & 1164.47 \\
\hline Porosity & 0.482 & 0.4863 & 0.4167 & 0.4956 \\
\hline Specific heat capacity, Dry $(\mathrm{J} / \mathrm{kg} \mathrm{K})$ & 880 & 810 & 770 & 730 \\
\hline Thermal conductivity, Dry, $\lambda(\mathrm{W} / \mathrm{m} \cdot \mathrm{K})$ & 0.15 & 0.17 & 0.114 & 0.11 \\
\hline Water vapour diffusion resistance factor, $\mu$ & 3.62 & 3.35 & 1 & 1 \\
\hline Reference water content, $\mathrm{W}_{80}\left(\mathrm{~kg} / \mathrm{m}^{3}\right)$ & 10.31 & 2.73 & 1.159 & 3.321 \\
\hline Free water content $\left(\mathrm{kg} / \mathrm{m}^{3}\right)$ & 380.95 & 285.71 & 42.86 & 122.76 \\
\hline Water absorption coefficient, $\mathrm{A}_{1}\left(\mathrm{~kg} / \mathrm{m}^{2} \cdot \mathrm{s}^{0.5}\right)$ & 0.47 & 0.22 & 0.0256 & 0.072 \\
\hline Typical Built-in moisture $\left(\mathrm{kg} / \mathrm{m}^{3}\right)$ & 125.46 & 87.35 & 4.21 & 14.34 \\
\hline
\end{tabular}

The moisture properties, porosity, water vapour diffusion resistance factor, and water absorption coefficient of substrate and coarse aggregates were measured in the laboratory as described in the following sections:

\subsubsection{Water content}

The unsaturated substrate and coarse aggregates' water contents were measured using the gravimetric analysis following NF ISO 16586 [66] in which they were put and kept inside of the oven at $105^{\circ} \mathrm{C}$ for $48 \mathrm{~h}$ to become completely dried out.

The free water content $\left(\mathrm{W}_{f}\right)$ is the ability of materials for holding the water content. Indeed, this parameter is dependent on the capillary action of materials, trapping the water molecules within their pore structure at a relative humidity of $100 \%$. However, due to the trapped air in the porous structure, the value of free water content is lower than the maximum water content $\left(\mathrm{W}_{\max }\right)$. In fact, the latter can be measured by the materials' porosity [67]. Therefore, a method for measuring the free water content of soil and coarse aggregates was used as suggested by other researchers [68,69]. In this method, a specific volume of the dry soil was put inside of the funnel in which a cotton wool in its neck was used to prevent washing soil particles away as shown in Fig. 4. After that, the specific amount of water was added to the dry soil using the measuring beaker to assess its waterholding capacity. By subtracting the collected water in the measuring cylinder from the water added using the measuring beaker, the trapped water by the dry soil was measured. Therefore, the free water content $\left(\mathrm{W}_{f}\right)$ for a specific volume of soil medium was obtained. As presented in Table 1, the $\mathrm{W}_{f}$ value for the substrate without coarse recycled materials was obtained $380.95 \mathrm{~kg} / \mathrm{m}^{3}$, which was close to the value for the conventional soil as obtained by other researchers [36]. 


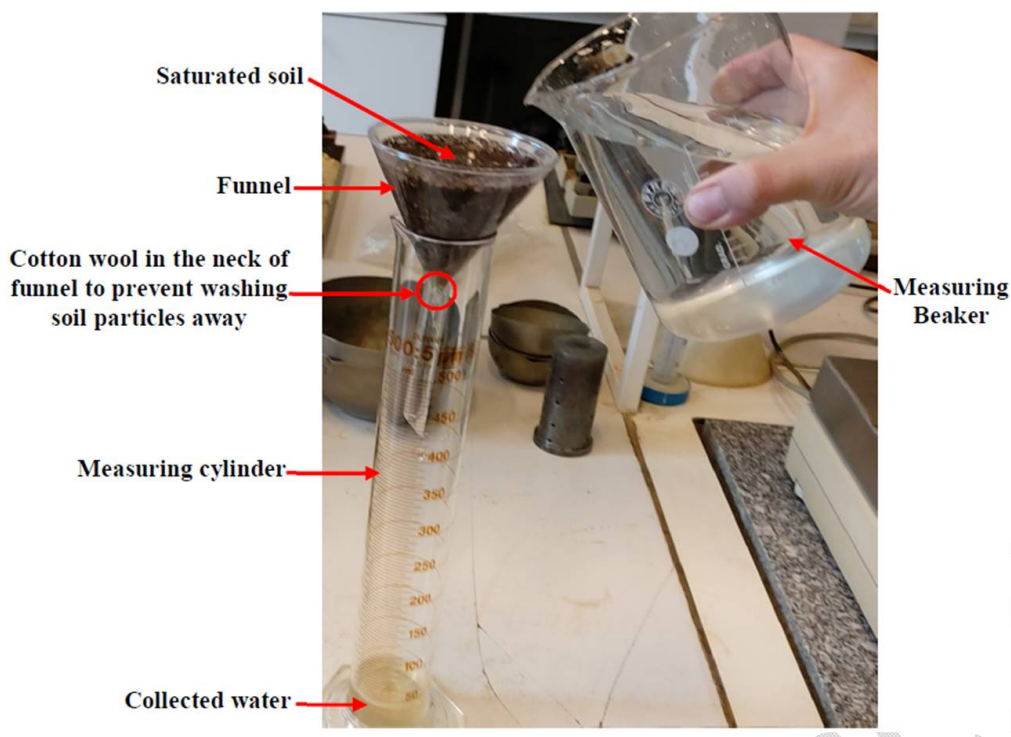

Fig. 4. Determining water-holding capacity of soil.

\subsubsection{Porosity}

To obtain the porosity of the drainage layer, the aggregate was first added to the beaker with a volume $900 \mathrm{~cm}^{3}$ as shown in Fig. 5. Then, the water was added to the same beaker to fill all voids among aggregates. Obviously, some water could be absorbed by pores of aggregates. The water absorption for recycled course aggregates was more than that for natural course aggregates as expected. To ensure that the aggregates' pores were fully filled with water, the beaker was closed and kept for $24 \mathrm{~h}$ after adding the water. Later on, the surface of water in the beaker with natural coarse aggregates remained constant. After $24 \mathrm{~h}$, the water surface slightly decreased in the beaker with recycled coarse aggregates due to their high porosity. Therefore, a few amount of water was added to the beaker with recycled coarse aggregates to return its surface to $900 \mathrm{~cm}^{3}$. According to the results, to fill all void spaces and pores of recycled coarse aggregates in beaker with the volume of $900 \mathrm{~cm}^{3}$, it was required to add $446 \mathrm{~cm}^{3}$. The corresponding value for natural course aggregate was $375 \mathrm{~cm}^{3}$. Considering the density of water of $1 \mathrm{~g} / \mathrm{cm}^{3}$, the porosity of drainage layer of aggregates was calculated using Eq. 4. This value for recycled and natural coarse aggregates was obtained $49.56 \%$ and $41.67 \%$, respectively. It is noteworthy that the aforementioned method was also used by other researchers [70] in which the aggregates can be submerged in the water for $24 \mathrm{~h}$ (the saturated surface-dry condition) to make them fully saturated.

Porosity of drainage layer $=\frac{\text { Volume of void spaces and pores of aggregates filled with water content }}{\text { Total volume }(\text { including volume of void spaces,aggregates and their pores) }} \times 100$

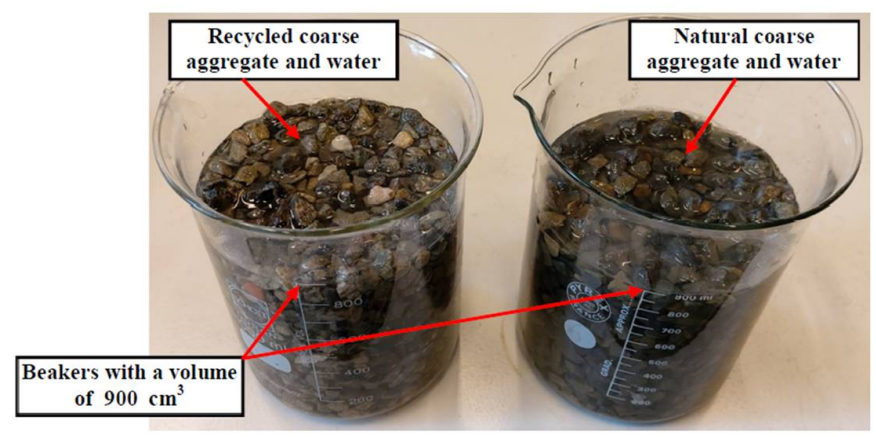

Fig. 5. Beakers filled with aggregates and water. 
By measuring the volume of void spaces among soil particles, the porosity of substrate was calculated using Eq. 5. For this purpose, the volume of dry substrate was determined. Considering the density of water of $1 \mathrm{~g} / \mathrm{cm}^{3}$, the dry substrate with the same volume was fully saturated by water to fill all void spaces among soil particles. Thereafter, the saturated soil was kept in an oven at 105 ${ }^{\circ} \mathrm{C}$ for $48 \mathrm{~h}$ to measure the water content in the sample using the gravimetric method in accordance with the NF ISO 16586 [66]. As per the results, the porosity of the substrate with coarse recycled materials was obtained $48.63 \%$. The corresponding value for the substrate without coarse recycled materials was $48.2 \%$.

Porosity of substrate $=\frac{\text { Volume of void spaces among soil particles }}{\text { Total volume (including volume of void spaces and soil particles) }} \times 100$

\subsubsection{Water vapour diffusion resistance}

The $\mu$-value is the water vapour diffusion resistance factor, representing the ratio of the diffusion coefficients of water vapour in air $\left(\mathrm{D}_{w 0}\right)$ and in the building materials $\left(\mathrm{D}_{w}\right)$ as shown in Eq. 6. Due to very low diffusion resistance of porous materials like coarse aggregate layers, the $\mu$-value was assumed to be close to 1, while higher amounts of this parameter should be measured and calculated for the materials with more diffusion resistance [71].

$\mu=\frac{\mathrm{D}_{w 0}}{\mathrm{D} w}$

According to DIN 52615 [72], in the physics of building materials, the vapour diffusion coefficient in air was calculated using an empirical equation given by Schirmer [73] as presented in Eq. 7:

$\mathrm{D}_{\mathrm{w} 0}=2.3 \times 10^{-5} \times \frac{\mathrm{P}_{0}}{\mathrm{P}_{\mathrm{L}}} \times\left(\frac{\mathrm{T}}{273.15}\right)^{1.81}$

Where $\mathrm{P}_{0}$ was the standard pressure in $\mathrm{Pa}(101325 \mathrm{~Pa}), \mathrm{P}_{\mathrm{L}}$ was ambient atmospheric pressure in $\mathrm{Pa}$ (for Liège city $=102300 \mathrm{~Pa}$ ), and $\mathrm{T}$ was absolute temperature in $\mathrm{K}(295.15 \mathrm{~K}$ ). Considering these values, the vapour diffusion coefficient in air, $\mathrm{D}_{w 0}$, was obtained $2.62 \times 10^{-5} \frac{\mathrm{m}^{2}}{\mathrm{~s}}$.

As mentioned by Togkalidou et al. [74], assuming the isothermal conditions and the ideal gas behavior of water vapour, the water vapour diffusivity $\left(\mathrm{D}_{w}\right)$ can be attributed to the water vapour permeability $\left(\mathrm{D}_{v}\right)$ as shown in Eq. 8:

$$
\mathrm{D}_{w}=\frac{\mathrm{D}_{v} \cdot \mathrm{R} \cdot \mathrm{T}}{\mathrm{M}}
$$

Where $\mathrm{D}_{w}$ is the water vapour diffusivity in $\frac{m^{2}}{s}, \mathrm{D}_{v}$ is water vapour permeability in $\frac{m^{2}}{s}, \mathrm{R}$ is molar gas constant in $\mathrm{m}^{2} \mathrm{~kg} \mathrm{~s}^{-2} \mathrm{~K}^{-1} \mathrm{~mol}^{-1}\left(8.3144598 \mathrm{~m}^{2} \mathrm{~kg} \mathrm{~s}^{-2} \mathrm{~K}^{-1} \mathrm{~mol}^{-1}\right)$, $\mathrm{T}$ is temperature in $\mathrm{K}$, and $\mathrm{M}$ is the water vapour molecular weight in $\frac{\mathrm{kg}}{\mathrm{mol}}\left(0.01801528 \frac{\mathrm{kg}}{\mathrm{mol}}\right)$.

According to ISO 12572 [75] and EN 1015-19 [76], the cup test method can be used for obtaining the water vapour permeability $\left(\mathrm{D}_{v}\right)$. In this method, the testing samples should be sealed on the open mouth of cups in which the water vapour pressure is kept constant at appropriate levels by means of saturated salt solutions. The cups are placed in a temperature controlled environment with a constant water vapour pressure different from that inside the cups. The rate of moisture transfer is determined from the change in weight of cups under steady state conditions. As per EN 1015-19 [76], the water vapour permeability $\left(\mathrm{D}_{v}\right)$ can be obtained by multiplying the water vapour permeance $(\Lambda)$ by the thickness of specimen $(\ell)$ as presented in Eq. 9: 
2 Where the units of water vapour permeance $(\Lambda)$ and thickness of specimen $(\ell)$ are $\frac{\mathrm{kg}}{\mathrm{m}^{2} \mathrm{~s} . \mathrm{Pa}}$ and $\mathrm{m}$, 3 respectively.

Eq. 10 can be used for obtaining the water vapour permeance $(\Lambda)$ :

$5 \quad \Lambda=\frac{1}{A \cdot \frac{\Delta P}{\left(\frac{\Delta G}{\Delta t}\right)}-R_{A}}$

Where $\mathrm{A}$ is the area of the open mouth of the test cup in $\mathrm{m}^{2}\left(0.02 \mathrm{~m}^{2}\right)$ based on EN 1015-19 [76], $\mathrm{R}_{\mathrm{A}}$ is the water vapour resistance of the air gap between the specimen and the salt solution $(0.048 \times$ $10^{9} \frac{\mathrm{Pa}^{2} \mathrm{~m}^{2} \mathrm{~s}}{\mathrm{~kg}}$ per $10 \mathrm{~mm}$ air gap), $\frac{\Delta \mathrm{G}}{\Delta \mathrm{t}}$ is the water vapour flux in $\frac{\mathrm{kg}}{\mathrm{s}}$, which can be obtained using the cup test method, and $\Delta P$ is the difference in water vapour pressure between the ambient air and the salt solution. Eq. 11 is proposed by BS 5250 [77] for the calculation of the pressure, $\mathrm{P}(\mathrm{Pa})$.

$\mathrm{P}=\varphi \times 610.5 \times e^{\frac{17.269 \times \theta}{237.3+\theta}}$

Where $\varphi$ is the relative humidity (unitless), and $\theta$ is the temperature in ${ }^{\circ} \mathrm{C}$.

Based on the above equations, cup test method was used for measuring the water vapour transmission rate (EN 1015-19) [76]. To calculate the water vapour permeance $(\Lambda)$ using Eq. 10, it was required to obtain some parameters including $A, R_{A}, \Delta P$, and $\frac{\Delta G}{\Delta t}$. Concerning this, cubic specimens with a thickness of $4 \mathrm{~cm}$ were prepared (Fig. 6(a)). The area of the open mouth of the test container (A in Eq. 10) was $0.02 \mathrm{~m}^{2}(0.14 \times 0.14 \mathrm{~m})$. The thickness of air layer (Fig. 6(a)) was equal to $10 \mathrm{~mm}$ used for determining $\mathrm{R}_{\mathrm{A}}$ in Eq. 10. To obtain the $\Delta \mathrm{P}$, the pressures inside and outside of the container $\left(\mathrm{P}_{\text {in }}\right.$ and $\left.\mathrm{P}_{\text {out }}\right)$ were calculated using Eq. 11. The container was placed in a conditioning chamber with a Heating Ventilation and Air Conditioning (HVAC) system (Fig. 6(b)), where according to the EN 1015-19 [76], the relative humidity and temperature were required to be $50 \pm 5 \%$ and $20 \pm 2{ }^{\circ} \mathrm{C}$, respectively. The outside relative humidity $(\varphi)$ and temperature $(\theta)$ in the conditioning chamber were equal to 0.51 and $22{ }^{\circ} \mathrm{C}$, respectively. Considering these values in Eq. $11, \mathrm{P}_{\text {out }}$ was obtained $1347.63 \mathrm{~Pa}$. Inside of the container $\left(22^{\circ} \mathrm{C}\right)$, a saturated solution of potassium nitrate $\mathrm{KNO}_{3}$ guaranteed a relative humidity of $93.2 \%$ as proposed by EN 1015-19 standard [76]. So, the inside relative humidity $(\varphi)$ and temperature $(\theta)$ in Eq. 11 were equal to 0.932 and $22{ }^{\circ} \mathrm{C}$, respectively. Based on these values, $\mathrm{P}_{\mathrm{in}}$ was obtained $2462.73 \mathrm{~Pa}$. Hence, $\Delta \mathrm{P}$ value was equal to 1115.1 Pa. Another parameter in Eq. 10 was $\frac{\Delta G}{\Delta t}$, representing the water vapour permeability rate. This parameter could be defined as a function of the amount of water vapour, passing through the soil specimen's surfaces. As shown in Fig. 7, $\frac{\Delta G}{\Delta t}$ values were determined from the graphs of substrate specimens, regardless of lines' negative slope. It is noteworthy that the lateral faces of plastic container were waterproofed with epoxy resin to prevent passing the moisture transfer from its edges as shown in Fig. 6(b); moreover, a stainless steel woven mesh at the bottom of the container of specimen was holding the sample in place.After obtaining all parameters in Eq. 10, the water vapour permeance $(\Lambda)$ was calculated. Later on, the water vapour permeability $\left(\mathrm{D}_{v}\right)$ was calculated using Eq. 9. After that, the water vapour diffusivity of specimen $\left(D_{w}\right)$ was obtained using 
1 Eq. 8. Finally, the water vapour diffusion resistance Factor $(\mu)$ was calculated using Eq. 6. 2 Therefore, the $\mu$-value of the substrate with and without coarse recycled materials was obtained 33.35 and 3.62, respectively. These values were nearly within the ranges given for soil materials $4 \quad[36,78,79]$.

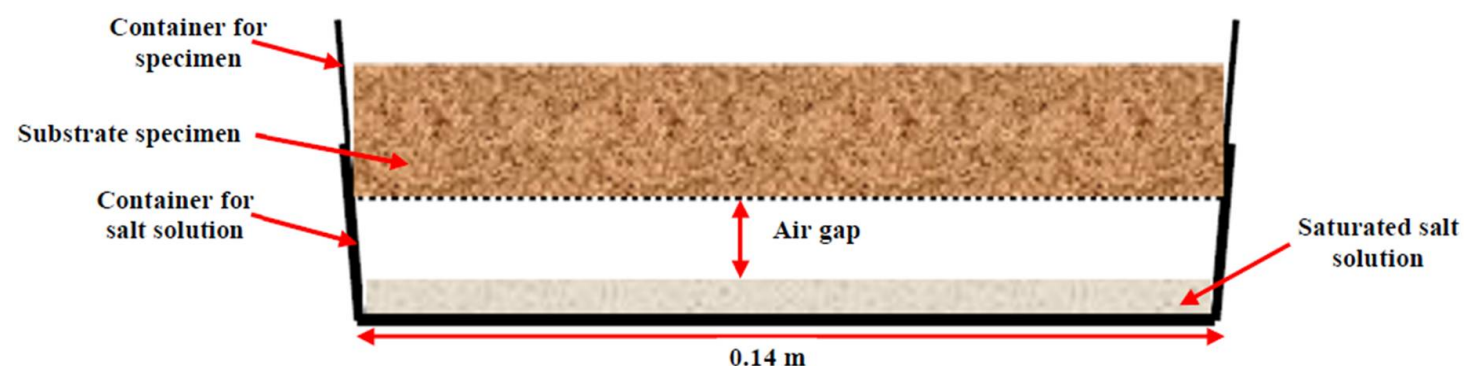

(a)

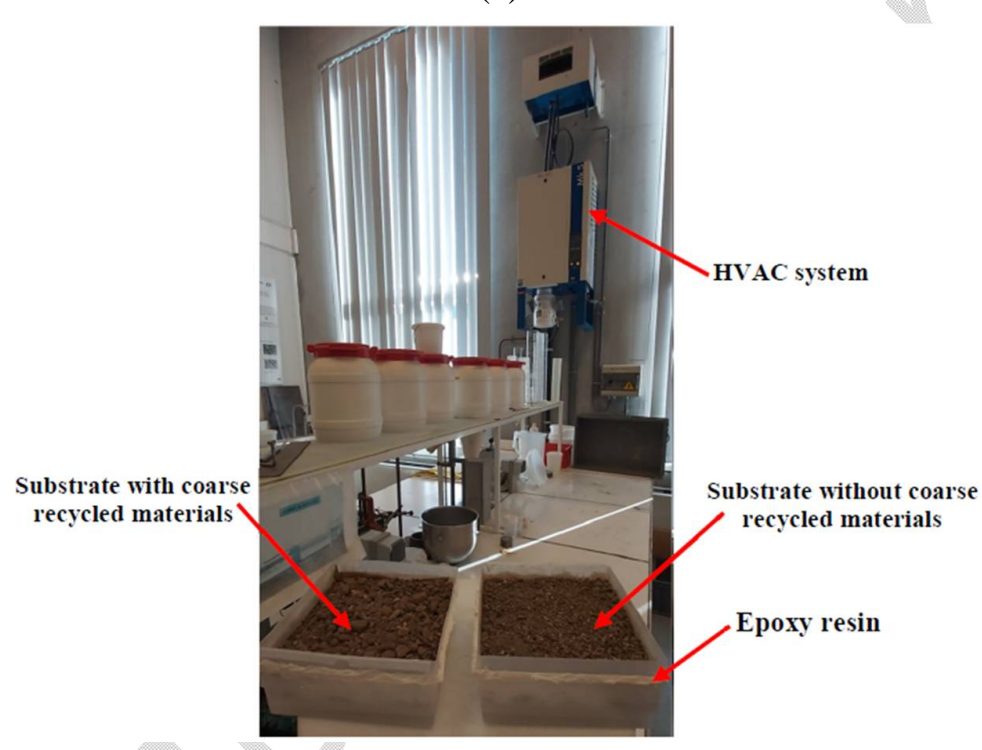

(b)

Fig. 6. A cross-sectional view of cup test method (a); Substrate specimens in the conditioning chamber (b).

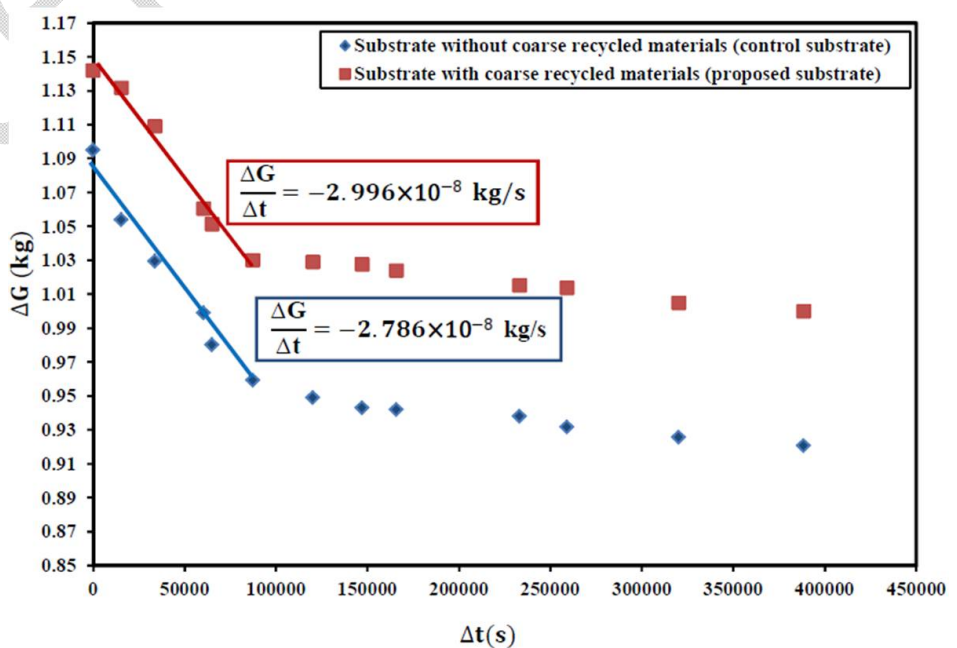

Fig. 7. The water vapour flux for the substrate with and without coarse recycled materials. 


\subsubsection{Water absorption coefficient}

A cross-sectional view of capillary test is shown in Fig. 8 (a). According to EN 1925 [80], the soil specimens were put in the right circular cylinder with a diameter of $50 \pm 5 \mathrm{~mm}$ and then, they were immersed in $3 \pm 1 \mathrm{~mm}$ of water on one of their sides. As indicated in Fig. 8 (b), the specimens were hung from the bottom of the weighing scale to record their weight over time by sucking the water from their bottom side. The water absorption coefficients for the substrate and coarse aggregates are shown in Fig. 9. Depending on the type of materials, this coefficient varies remarkably. For instance, the water absorption coefficients of the substrate with and without coarse recycled materials were obtained $0.22 \mathrm{~kg} / \mathrm{m}^{2} \cdot \mathrm{s}^{0.5}$ and $0.47 \mathrm{~kg} / \mathrm{m}^{2} \cdot \mathrm{s}^{0.5}$, respectively, which were within the ranges given by Soudani et al. [81] for soil materials.

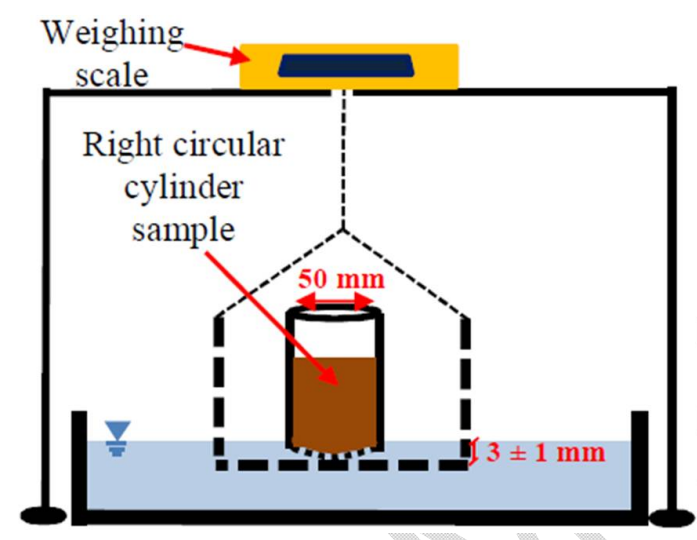

(a)

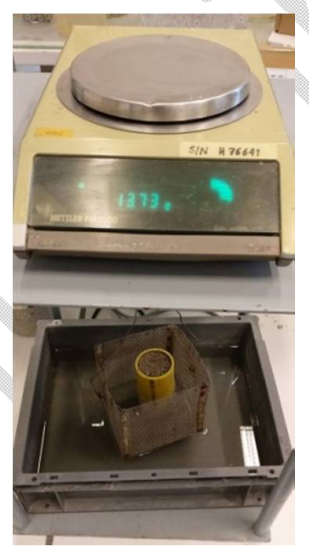

(b)

Fig. 8. A cross-sectional view of capillary test (a); testing setup in lab (b).

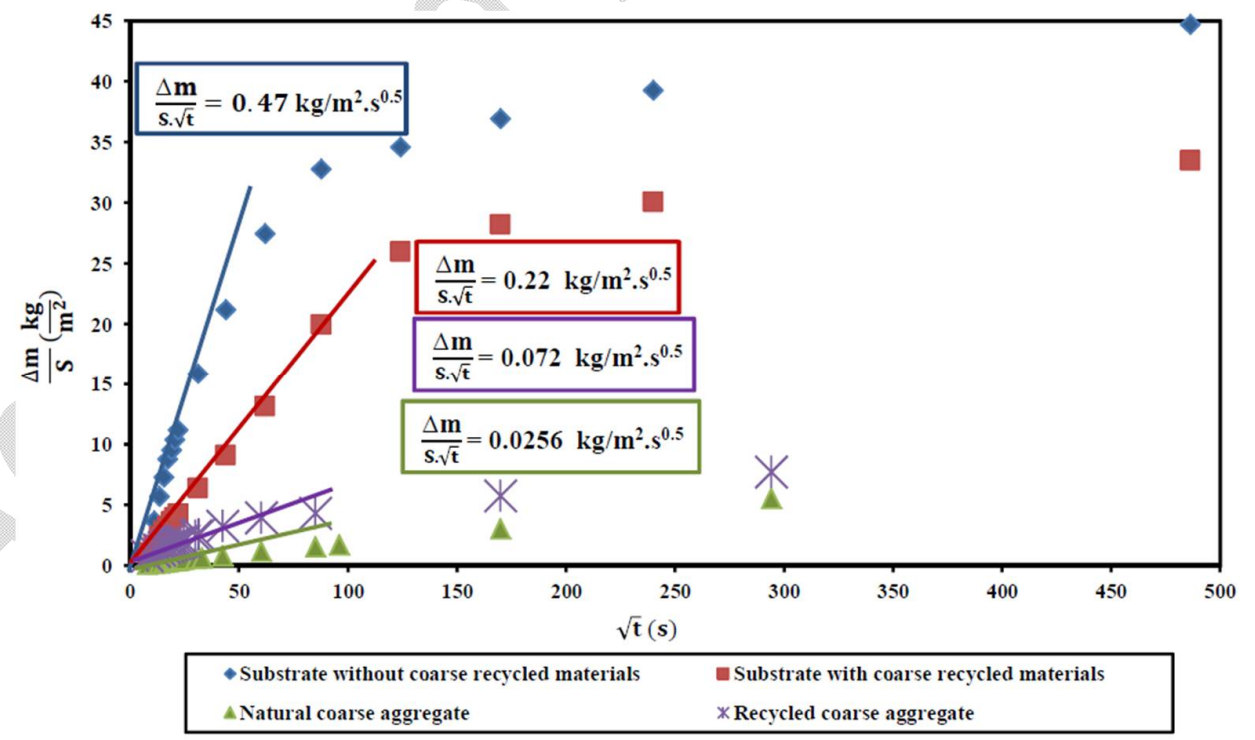

Fig. 9. Water absorption coefficients for the materials used for the green roof layers.

\subsubsection{Modelling green roof layers parameters}

In this study, the WUFI simulation software was implemented for modelling and optimizing the green roof layers' thickness. To reliably validate the numerical models with the roofing systems' 
$5 \quad \mathrm{~W}=\mathrm{W}_{f} \times \frac{(b-1) \cdot \varphi}{b-\varphi}$ assumed $0.8[71,82]$.

$\mathrm{b}_{1}=\frac{\left(\frac{\lambda(w)}{\lambda_{0}}-1\right) \times \rho_{s}}{W}$

results, the green roof layers were automatically meshed using the fine grids available in the WUFI software. After introducing the free water content $\left(\mathrm{W}_{f}\right)$ to the software, the moisture storage function (Eq. 12) could be automatically used by WUFI [71,82] to obtain the moisture storage graphs of substrate and coarse aggregates as shown in Fig. 10 (a).

Where $\mathrm{W}$ is the moisture content corresponding to relative humidity $\left(\frac{\mathrm{kg}^{3}}{\mathrm{~s}}\right)$, and $\mathrm{b}$ is the approximation factor that can be empirically specified by recognizing the moisture content of substrate and coarse aggregates in equilibrium at a relative humidity of 0.8 [83]. This factor ranges from 0 to 1 and it is close to 1 for free water saturation [84]. Note that the typical built-in moisture was the moisture corresponding to the materials' relative humidity of $0.8[71,82]$. This parameter for the substrate and coarse aggregates was calculated using Eq. 12 as presented in Table 1. Moreover, to obtain the moisture storage graphs of materials in WUFI software, the reference water content, $\mathrm{W}_{80}$, was calculated using Eq. 12 when the relative humidity of materials should be

Another parameter was the moisture-induced heat conductivity supplement $\left(b_{1}\right)$, which could be defined as the percentage increment in thermal conductivity per the percentage increment in moisture content. To calculate $b_{1}$, the values of bulk density, thermal conductivity of materials with a specific amount of water content were substituted into Eq. 13 [85].

Where the $\lambda(\mathrm{w})$ and $\lambda_{0}$ are the thermal conductivity of materials in moist and dry conditions, respectively $(\mathrm{W} / \mathrm{m} \cdot \mathrm{K})$. After introducing $\mathrm{b}_{1}$ values to the WUFI software, a linear relationship between the thermal conductivity and the normalized water content could be automatically generated using Eq. 13 as shown in Fig. 10 (b) $[36,85,86]$. The normalized water content was the ratio of the water content $\left(\mathrm{kg} / \mathrm{m}^{3}\right)$ to the maximum water content $\left(\mathrm{kg} / \mathrm{m}^{3}\right)$.

The capillary uptake of water for the fully saturated materials can be defined as a parameter in WUFI software, namely the liquid transport coefficient for suction $\left(\mathrm{D}_{w s}\right)$. The liquid transport coefficient for redistribution $\left(\mathrm{D}_{w w}\right)$ represents the spread of the imbibed water when the fully saturated condition is finished. This process is associated with the beginning of the water redistribution through the material's depth without uptaking the water $[67,71]$. The $\mathrm{D}_{\mathrm{ws}}$ parameter could be related to the normalized water content using Eq. 14 after introducing the materials' water absorption coefficient to the WUFI software as shown in Fig. 10 (c) $[71,87,88]$.

$\left.\mathrm{D}_{w s}(w)=3.8\left(\frac{A_{1}}{w_{f}}\right)^{2} \times 1000^{\left(\frac{w}{w_{f}}\right.}\right)^{-1}$

Where $A_{1}$ is the water absorption coefficient. As shown in Fig. $10(d)$, the $D_{w w}$ parameter was automatically identical to the $\mathrm{D}_{w s}$ parameter using the WUFI software for simplicity $[36,71,89]$. 


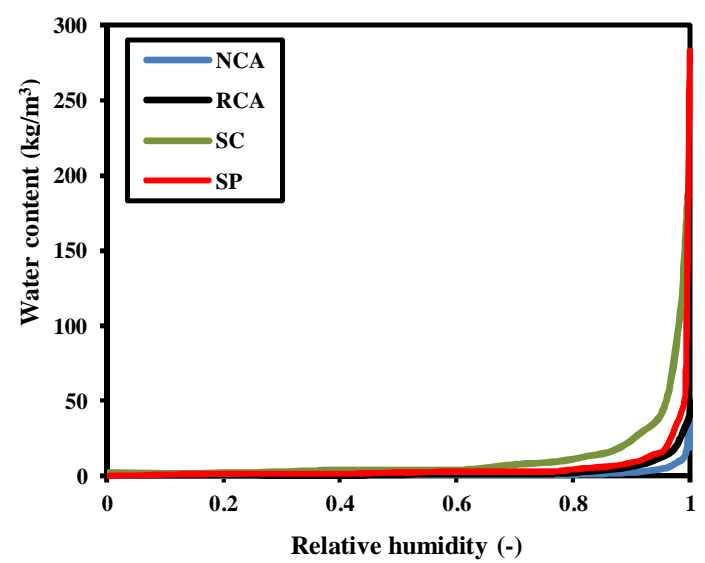

(a)

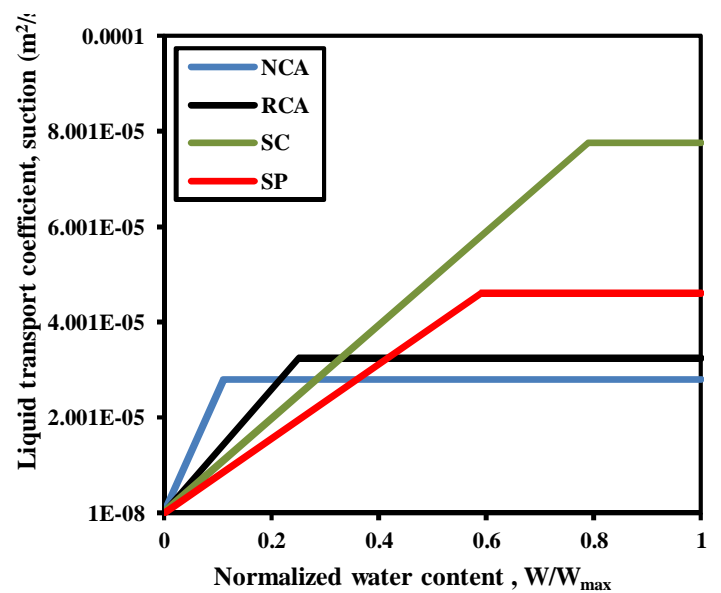

(c)

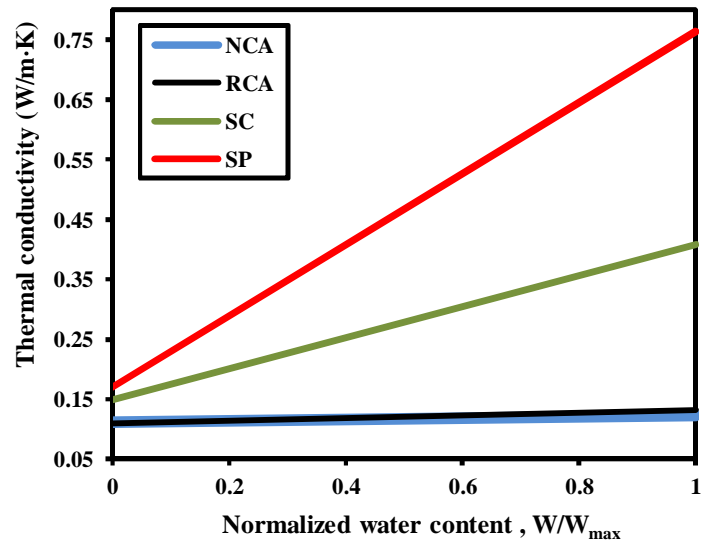

(b)

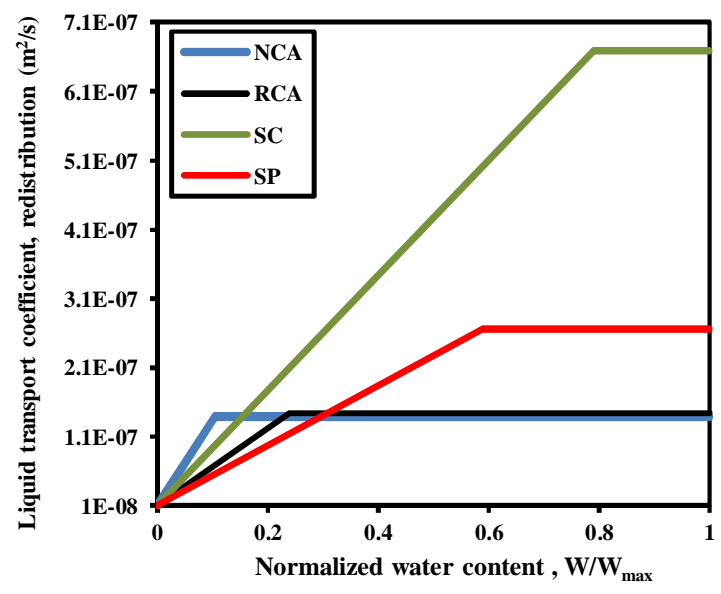

(d)

Fig. 10. Moisture storage graph (a); thermal conductivity versus materials' water content (b) ; liquid transport coefficient for the capillary suction $\left(\mathrm{D}_{\mathrm{ws}}\right)(\mathrm{c})$; liquid transport coefficient, for the capillary redistribution $\left(\mathrm{D}_{\mathrm{ww}}\right)(\mathrm{d})$.

\subsubsection{Green roofs' geometrical characteristics}

Table 2 presents the green roof layers' geometrical characteristics. After validation of the control and the proposed green roof models with $15-\mathrm{cm}$ substrate and 5-cm coarse aggregate layers (NCA5SC15 and RCA5-SP15), their thicknesses were numerically changed using the WUFI software to achieve an optimum design of roofing systems. First, the drainage layer's thickness was changed from $5 \mathrm{~cm}$ to $4,6,7$, and $8 \mathrm{~cm}$ when the substrate layer's thickness was kept $15 \mathrm{~cm}$ for both the control and the proposed green roof models. Later on, the substrate's thickness was changed from $15 \mathrm{~cm}$ to $12,18,21 \mathrm{~cm}$ when the drainage layer's thickness was kept $5 \mathrm{~cm}$ for both the control and the proposed green roof models. After that, as presented in Table 1, the substrate and drainage layers' thickness was simultaneously changed by keeping the ratio of substrate to drainage layer constant (3). 
Table 2. Green roofs' geometrical configurations.

\begin{tabular}{clcc}
\hline \multirow{2}{*}{ No. } & \multirow{2}{*}{ Specimens ID } & \multicolumn{2}{c}{ Thickness (cm) } \\
\cline { 3 - 4 } & & Drainage layer & Substrate \\
\hline 1 & NCA $^{\text {a } 4-S C ~} 15$ & 4 & 15 \\
2 & NCA5-SC15 $^{\mathrm{b}}$ & 5 & 15 \\
3 & NCA6-SC15 & 6 & 15 \\
4 & NCA7-SC15 & 7 & 15 \\
5 & NCA8-SC15 & 8 & 15 \\
6 & NCA5-SC12 & 5 & 12 \\
7 & NCA5-SC18 & 5 & 18 \\
8 & NCA5-SC21 & 5 & 21 \\
9 & NCA4-SC12 & 4 & 12 \\
10 & NCA6-SC18 & 6 & 18 \\
11 & NCA7-SC21 & 7 & 21 \\
12 & RCA 4-SP 15 & 4 & 15 \\
13 & RCA5-SP15 & 5 & 15 \\
14 & RCA6-SP15 & 6 & 15 \\
15 & RCA7-SP15 & 7 & 15 \\
16 & RCA8-SP15 & 8 & 15 \\
17 & RCA5-SP12 & 5 & 12 \\
18 & RCA5-SP18 & 5 & 18 \\
19 & RCA5-SP21 & 5 & 21 \\
20 & RCA4-SP12 & 4 & 12 \\
21 & RCA6-SP18 & 6 & 18 \\
22 & RCA7-SP21 & 7 & 21 \\
\hline
\end{tabular}

${ }^{a}$ Natural coarse aggregate

${ }^{\mathrm{b}}$ Substrate without coarse recycled materials (control substrate)

${ }^{c}$ Recycled coarse aggregate

${ }^{\mathrm{d}}$ Substrate with coarse recycled materials (proposed substrate)

\section{Results}

\subsection{Heat transfer measurement using the ISO-conversion method}

The thermal conductivity and $\mathrm{R}_{\mathrm{c}}$-values of green roof layers are presented in Figs. 11 and 12 , respectively. The heat flux measurements were based on the Average Method's criteria given by ISO 9869-1 [56].

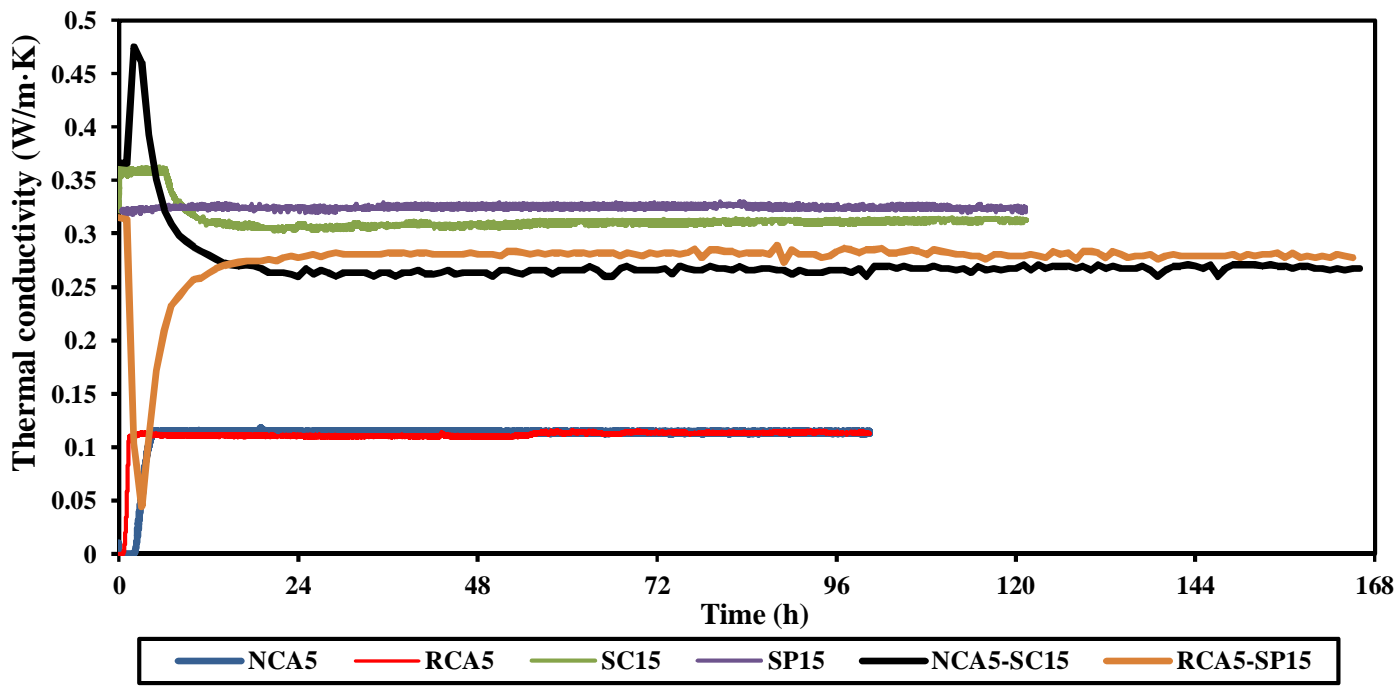

Fig. 11. Green roof layers' thermal conductivity. 


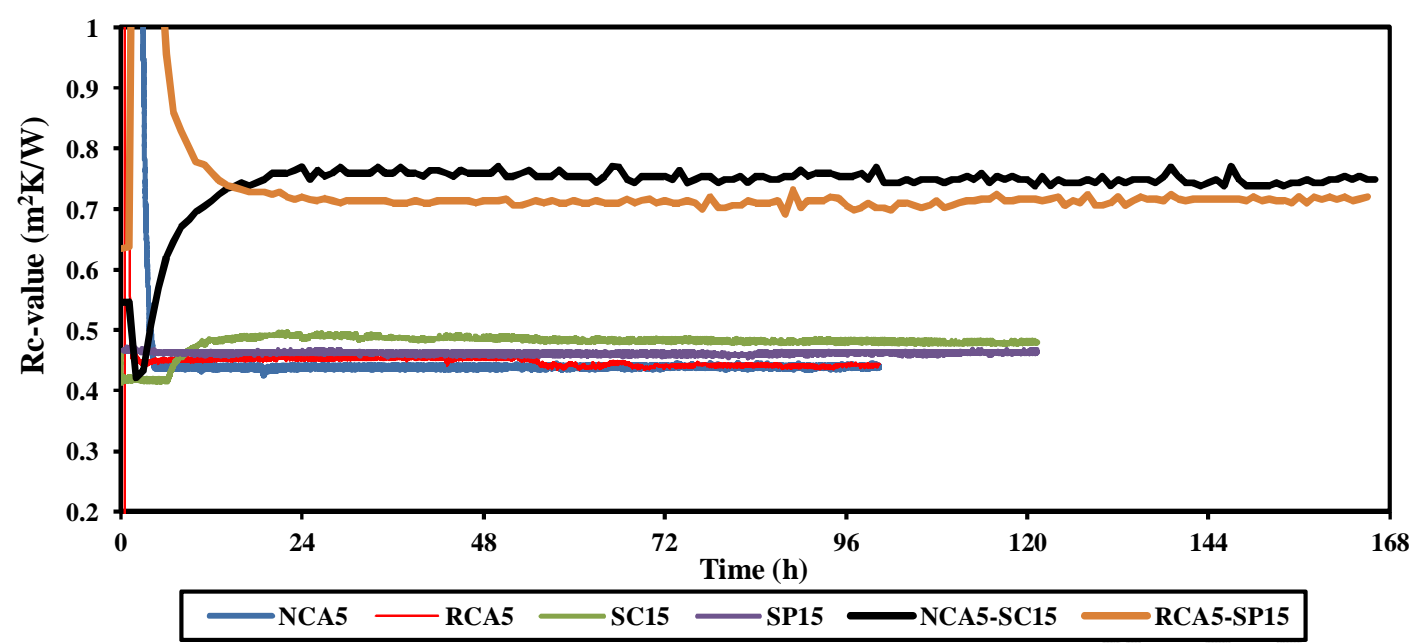

Fig. 12. Green roof layers' Rc-value curves.

According to the first requirement given by the ISO-conversion method, the measurement period should take at least $72 \mathrm{~h}$. Table 3 presents all specimens' test durations. For the control and the proposed green roof specimens (NCA5-SC15 and RCA5-SP15), the last $118 \mathrm{~h}$ of the test duration was considered for assessing their $\mathrm{R}_{\mathrm{c}}$-value convergence. The last $76 \mathrm{~h}$ of the test duration for the natural and recycled coarse aggregate layers (NCA5 and RCA5) was supposed to assess their $\mathrm{R}_{\mathrm{c}^{-}}$ value convergence. The last $73 \mathrm{~h}$ of the test duration for the unsaturated substrate without and with coarse recycled materials (SC15 and SP15) was considered as their convergence duration.

Table 3. Green roof layers' thermal properties.

\begin{tabular}{lcccccc}
\hline Specimens ID & NCA5 & RCA5 & SC15 & SP15 & NCA5-SC15 & RCA5-SP15 \\
\hline Test duration $(\mathrm{h})$ & 101 & 101 & 122 & 122 & 166 & 166 \\
Convergence duration $(\mathrm{h})$ & 76 & 76 & 73 & 73 & 118 & 118 \\
Thermal conductivity unsaturated, $(\mathrm{W} / \mathrm{m} \cdot \mathrm{K})$ & 0.114 & 0.11 & 0.31 & 0.32 & 0.27 & 0.28 \\
Rc-value $\left(\mathrm{m}^{2} \mathrm{~K} / \mathrm{W}\right)$ & 0.44 & 0.446 & 0.48 & 0.46 & 0.75 & 0.72
\end{tabular}

As per the second requirement given by ISO 9869-1 [56], the value calculated at the end of the data set should not deviate more than $\pm 5 \%$ from the respective value obtained $24 \mathrm{~h}$ before. Concerning this, $24 \mathrm{~h}$ before the end of the data set, the Rc-values for NCA5-SC15, RCA5-SP15, $\mathrm{SC} 15$, SP15, NCA5, and RCA5 were $0.743,0.713,0.481,0.462,0.443$, and $0.44 \mathrm{~m}^{2} \mathrm{~K} / \mathrm{W}$, respectively. The resulting values at the end of the data set were $0.75,0.72,0.48,0.463,0.443$, and $0.446 \mathrm{~m}^{2} \mathrm{~K} / \mathrm{W}$, respectively. Therefore, the difference between the Rc-values at the end and $24 \mathrm{~h}$ before the end of the data set was not more than $1.4 \%$, satisfying the second requirement given by ISO 9869-1 [56].

Based on another requirement of the ISO-conversion method, the resulting value when applying the method to the first $67 \%$ of data should not deviate by more than $\pm 5 \%$ from the respective value when analyzing the last $67 \%$ of the data. The results showed that the average $\mathrm{R}_{\mathrm{c}}$-values for the first $67 \%$ of the convergence duration for NCA5-SC15, RCA5-SP15, SC15, SP15, NCA5, and RCA5 were $0.748,0.715,0.481,0.461,0.441$, and $0.449 \mathrm{~m}^{2} \mathrm{~K} / \mathrm{W}$, respectively. The corresponding values for the last $67 \%$ convergence duration were $0.746,0.724,0.48,0.462,0.44$, and $0.446 \mathrm{~m}^{2} \mathrm{~K} / \mathrm{W}$, respectively. According to the results, the difference between the obtained Rc-values for the first 
and the last $67 \%$ of the convergence duration was not more than $1.3 \%$. In general, the results of heat transfer measurements met the ISO-conversion method's requirements.

\subsection{Validation of the models with the roofing systems}

The air relative humidity variations at the top and bottom of the control and proposed green roofs as well as temperature fluctuations through their depths are shown in Figs. 13(a) and 13(b). For the validation of the models, the temperature fluctuations through their depths were compared with those of roofing systems (NCA5-SC15 and RCA5-SP15).

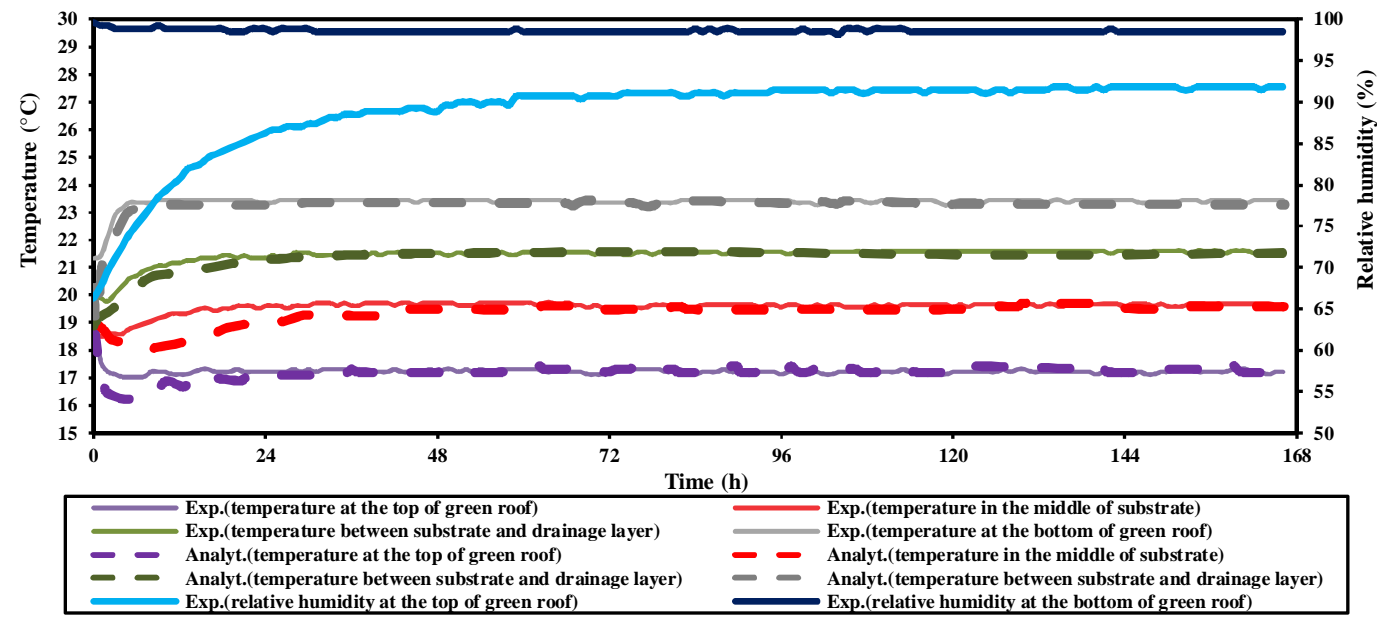

(a)

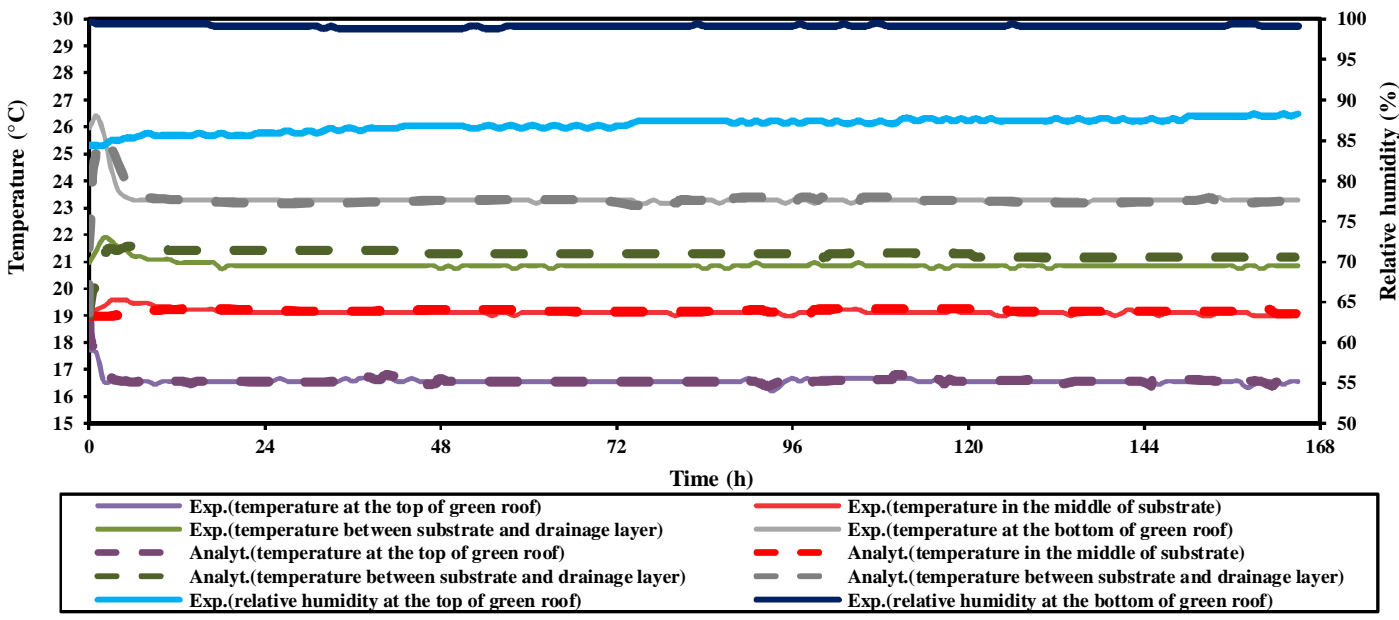

(b)

Fig. 13. Experimental results and modeling outputs for the control green roof specimen, NCA5$\mathrm{SC15}$, (a) and the proposed green roof specimen, RCA5-SP15, (b).

As expected, the temperature distribution at the top and the bottom of green roof models had the same trend as observed for the roofing systems. Based on the results of the control green roof specimen during the convergence period, the average temperatures of $19.64{ }^{\circ} \mathrm{C}$ and $21.56{ }^{\circ} \mathrm{C}$ were attained in the middle of the substrate and between the substrate and drainage layer, respectively. The corresponding temperatures for the control model were $19.6{ }^{\circ} \mathrm{C}$ and $21.5{ }^{\circ} \mathrm{C}$, respectively. According to the proposed green roof specimen' results during the convergence period, the average temperatures of $19.1{ }^{\circ} \mathrm{C}$ and $20.84{ }^{\circ} \mathrm{C}$ were attained in the middle of the substrate and between the substrate and drainage layers, respectively. The corresponding temperatures were equal to $19.05{ }^{\circ} \mathrm{C}$ 
and $21.19{ }^{\circ} \mathrm{C}$ for the proposed model. Consequently, the general trend of the temperature distribution through the models' depth was nearly the same as observed for the roofing specimens. Moreover, the difference between the modelling and experimental specimens' temperatures through the layers' depth was no more than $1.7 \%$.

\subsection{Effect of layers' thickness}

\subsubsection{Thickness of drainage layer}

By changing drainage layer's thickness, the average temperature values within green roof layers' depth were obtained during the convergence duration of Rc-value (the last $118 \mathrm{~h}$ of the test duration) as presented in Fig. 14.

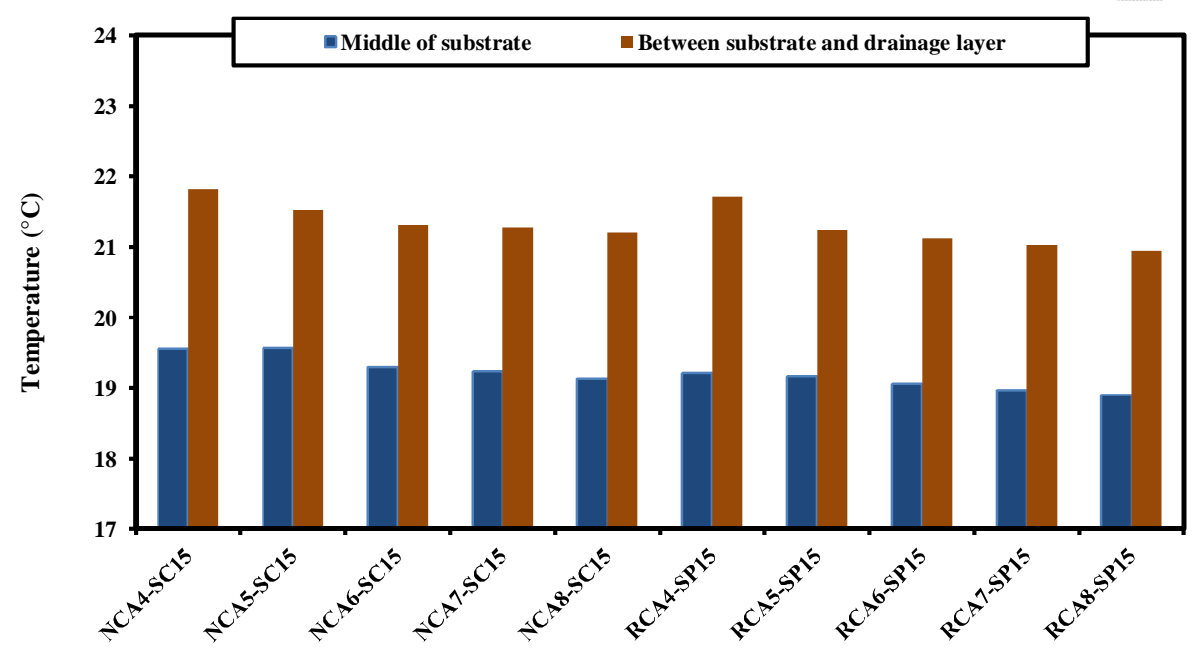

Fig. 14. Effect of drainage layer's thickness on the average temperature value in the models' depth.

By increasing the drainage layer's thickness, its optimum design could be determined when no change in the temperature through green roof's depth was observed. The temperature between substrate and drainage layer for the control models with different thicknesses of drainage layer was ranging from $21.2{ }^{\circ} \mathrm{C}$ to $21.82{ }^{\circ} \mathrm{C}$. It can be stated that there was a mild decrease in temperature when the thickness of drainage layer of natural coarse aggregate increased. However, the average temperature value for 6-cm drainage layer was found to be nearly the same as 7 - and 8 -cm drainage layer $\left(21.2{ }^{\circ} \mathrm{C}\right)$. The same result was observed in the middle of substrate layer, where the temperature for the models with 6-, 7- and 8-cm drainage layer was near to $19.2{ }^{\circ} \mathrm{C}$. On the other hand, the temperature of $21{ }^{\circ} \mathrm{C}$ was observed between substrate and drainage layer for the proposed models with 6-, 7-, and 8-cm drainage layer. Moreover, the temperature in the middle of substrate layer for the proposed models was about $18.9{ }^{\circ} \mathrm{C}$.

\subsubsection{Thickness of the substrate layer}

The average temperature values within green roof layers' depth were obtained during the convergence duration of Rc-value (Fig. 15) when the unsaturated substrate layer's thickness was changed. 


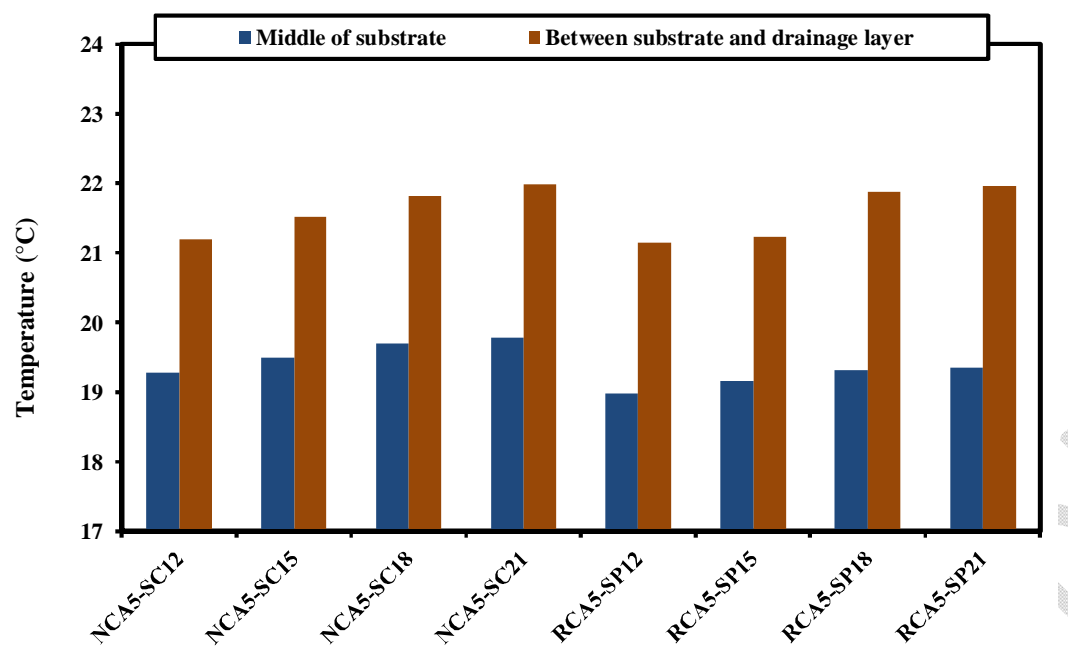

Fig. 15. Effect of substrate layer's thickness on the average temperature value in the models' depth.

The optimum design of substrate layer was ascertained by increasing its thickness when no change in the temperature was observed through green roof's depth. For the control models, the middle of the substrate's temperature for green roofs with 12-, and 15-cm substrate layer was 19.28 ${ }^{\circ} \mathrm{C}$ and $19.5^{\circ} \mathrm{C}$, respectively. Besides, the average temperature value for 18 -cm substrate layer was nearly the same as $21-\mathrm{cm}$ substrate layer $\left(19.7^{\circ} \mathrm{C}\right)$. The same result was obtained between the substrate and drainage layer, where the temperature for the control models with $18-, 21-\mathrm{cm}$ substrate layer was near to $21.9{ }^{\circ} \mathrm{C}$. On the other hand, the temperature value of $19.32{ }^{\circ} \mathrm{C}$ was obtained in the middle of substrate for the proposed model with 18- and 21-cm substrate containing coarse recycled materials. Similar to this, the temperature between the substrate and drainage layer for the proposed model with $18-\mathrm{cm}$ substrate was obtained near to the same as the propose model with $21-\mathrm{cm}$ substrate $\left(21.9{ }^{\circ} \mathrm{C}\right)$.

\subsubsection{Thickness with constant ratio of substrate to drainage layer}

By simultaneously changing the substrate and drainage layers' thickness, the average temperature values within green roof layers were attained as shown in Fig. 16.

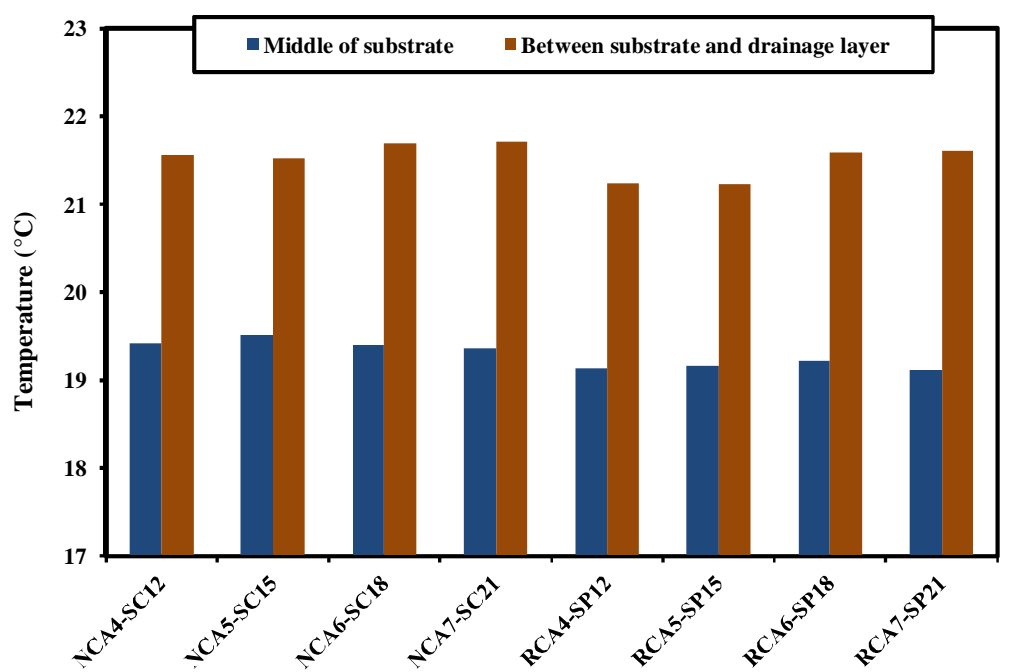

Fig. 16. Effect of substrate and drainage layers' thickness on the average temperature value in the models' depth. 
As per the modelling outputs, no remarkable difference was observed in the middle of the substrate's temperature when the substrate and drainage layers' thicknesses were simultaneously changed. As an example, the aforementioned temperature for the control models ranged from $19.4^{\circ} \mathrm{C}$ to $19.5^{\circ} \mathrm{C}$. The range of $19.1-19.2^{\circ} \mathrm{C}$ was obtained for the proposed models. On the other hand, a moderate temperature increment between the substrate and drainage layer was observed for both control and proposed models by increasing green roof layers' thickness. However, this temperature for the model with $18-\mathrm{cm}$ substrate was obtained near to the same as the model with $21-\mathrm{cm}$ substrate. For instance, this temperature for the proposed models with $18-$, and $21-\mathrm{cm}$ substrate (RCA6-SP18 and RCA7-SP21) was about $19.2{ }^{\circ} \mathrm{C}$. The control models' corresponding temperature for the same designs of substrate layer was about $19.4{ }^{\circ} \mathrm{C}$.

\section{Discussion}

\subsection{Green roof layers' thermal performance}

Table 3 presents the thermal conductivity and Rc-value of roofing systems' layers following the ISO-conversion method. The aforementioned parameters can be used for the materials' thermal transmission and resistance $[18,19,90,91]$. The thermal conductivity of $0.11 \mathrm{~W} / \mathrm{m} \cdot \mathrm{K}$ and Rc-value of $0.44 \mathrm{~m}^{2} \mathrm{~K} / \mathrm{W}$ were obtained for both the natural and recycled coarse aggregate layers (NCA5 and RCA5) as presented in Table 3. Although natural coarse aggregates' properties were different to that of the recycled coarse aggregates, the thermal performance of the layer including either the natural coarse aggregates (NCA5) or recycled coarse aggregates (RCA5) were found to be similar to each other. It is noteworthy that the building materials' heat resistance can be improved by trapping the air-voids among their particles [18,19,92-94]. Therefore, similar thermal performance of NCA5 and RCA5 could be attributed to the air-voids among coarse aggregates and indeed, their Rc-values were more affected by air-voids than coarse aggregate types.

The materials used for the soil medium play a key role for improving the heat resistance of green roof systems. Therefore, the thermal sensitivity of substrate with different types of materials should be assessed [18,36,38]. As per the modelling outputs, no significant difference was observed between the thermal conductivity of unsaturated substrate layer without coarse recycled materials, $\mathrm{SC} 15(0.31 \mathrm{~W} / \mathrm{m} \cdot \mathrm{K})$ and the unsaturated substrate layer with coarse recycled materials, SC15, $(0.32$ $\mathrm{W} / \mathrm{m} \cdot \mathrm{K}$ ). Following this, the Rc-value of the former, $0.48 \mathrm{~m}^{2} \mathrm{~K} / \mathrm{W}$, was close to that of the latter, $0.46 \mathrm{~m}^{2} \mathrm{~K} / \mathrm{W}$, demonstrating less than $4.3 \%$ difference between their thermal resistances. It can be stated that the substrate layer's thermal performance was not changed so much with the presence of coarse recycled materials. Therefore, they created a sufficient thermal resistance and water retention capacity like soil particles for the substrate layer. In brief, both the control and the proposed substrate layers (SC15 and SP15) provided a sufficient thermal mass for the roofing systems, similar to the conventional substrate layers used by other researchers for green roofs $[27,95]$.

The difference between the control and the proposed green roof systems (NCA5-SC15 and RCA5-SP15) showed a narrow difference between their Rc-values (4.2\%). This small difference was due to the effect of coarse recycled materials on the substrate layer, even though it was negligible. The recycled coarse aggregate for the drainage layer and coarse recycled materials for the substrate layer of green roof systems was able to provide a sufficient thermal resistance. Note that the thickness of substrate layer was three times more than that of coarse aggregates as the drainage layer, while the Rc-value of the former was $9 \%$ more than that of the latter at the most. It is worth bearing in mind that the coarse aggregate layer's thermal resistance could be better than 
that of the unsaturated substrate layer by considering an equal thickness for both of them owing to air-voids among aggregates, generating high heat resistance for the drainage layer.

\subsection{Parametric study}

Assuming a constant thickness for the substrate layer $(15 \mathrm{~cm})$, no change was observed among the green roof models with 6-, 7- and 8-cm coarse aggregate layers. This result was observed for both the control and the proposed green roof models, due to the fact that their thermal performance was dominated more by the air-voids among aggregates than the coarse aggregate types. That's why the Rc-value of green roofs either with the natural coarse aggregates or with the recycled coarse aggregates as the drainage layer was obtained nearly the same as presented in Table 3. Based on the above, the presence of air-void among coarse aggregates with 6-cm drainage layer sufficiently provided the thermal performance for green roofs. Therefore, the NCA6-SC15 and RCA6-SP15 models were the optimum designs of the roofing systems, while a constant thickness of $15 \mathrm{~cm}$ was assumed for the substrate layer.

Increasing the unsaturated substrate layer's thickness contributed to improving the thermal resistance of the models, similarly to what Sun et al. [39] concluded. However, considering a constant thickness for the drainage layer $(5 \mathrm{~cm})$, no difference was seen between the green roof models with 18 - and $21-\mathrm{cm}$ substrate layer. It can be said that the positive influence of the unsaturated substrate layer gradually decreased by increasing its thickness as observed by other researchers [40]. This may be due to the fact that more moisture could be absorbed by one side of the thicker substrate $(21 \mathrm{~cm})$, leading to decreasing the participation of the soil's water content for reducing the heat flux through the substrate layer as revealed by Sun et al. [39]. So, it was required to determine the unsaturated substrate layer's optimum thickness somewhere in the middle $(18 \mathrm{~cm})$ [18]. As a result, the NCA5-SC18 and RCA5-SP18 models were introduced as the optimum designs of the roofing systems, while a constant thickness of $5 \mathrm{~cm}$ was assumed for the drainage layer.

By simultaneously changing the substrate and drainage layers' thickness and keeping constant their thickness ratio, the models with $6-\mathrm{cm}$ drainage layer and $18-\mathrm{cm}$ unsaturated substrate layer (NCA6-SC18 and RCA6-SP18) were introduced as optimum designs of the roofing systems. Note that the use of lightweight roofing systems for the rooftops has been suggested by researchers $[18,19]$. Therefore, the proposed green roof (RCA6-SP18) was suggested to be employed in this regard owing to its lower weight than the control green roof (NCA6-SC18).

In general, for the control models, a separate increase in the substrate and drainage layers' thickness resulted in the introduction of NCA5-SC18 and NCA6-SC15 as the optimum designs of the roofing systems, while NCA6-SC18 was assumed as the optimum design by simultaneously changing the substrate and drainage layers' thickness. Therefore, a simultaneous increment in the unsaturated substrate and drainage layers' thickness contributed to creating better thermal performance for the green roofs. Of all optimum designs for the control models, the lowest weight was obtained for NCA6-SC15 $\left(247.48 \mathrm{~kg} / \mathrm{m}^{2}\right)$ by considering the materials' density values in Table 1. Among all optimum designs for the proposed models, RCA6-SP15 had the lowest weight $\left(220.01 \mathrm{~kg} / \mathrm{m}^{2}\right)$. In brief, it is recommended to use the coarse recycled materials for the roofing systems' layers owing to their low weight and sufficient thermal performance. 


\section{Conclusions}

This study experimentally assessed the thermal resistance of green roof layers with coarse recycled materials following ISO 9869-1 standard. The initial moisture and thermal properties of the layers were simultaneously simulated and their thickness was optimized. Based on the experimental and modelling outputs for the roofing systems, the following conclusions can be considered:

- On the basis of ISO 9869-1 standard, the Rc-value of the drainage layer either with the natural coarse aggregates or with recycled coarse aggregates was the same $(0.44$ $\left.\mathrm{m}^{2} \mathrm{~K} / \mathrm{W}\right)$. It means that drainage layer' thermal resistance was mainly influenced by the air-voids among coarse aggregates and not by the porosity of recycled aggregates.

- A small difference (4.3\%) appeared between the Rc-value of the control substrate layer (SC15) and the proposed substrate layer (SP15). Therefore, considering the fact that the substrate layer' thermal performance was dependent on soil moisture content, the coarse recycled materials provided an adequate thermal resistance, similar to soil particles for the substrate layer.

- A small difference (4.2\%) was observed between the Rc-value of the control and the proposed green roof systems (NCA5-SC15 and RCA5-SP15), owing to the presence of coarse recycled materials in the substrate layer of the latter. However, this negligible difference demonstrated a sufficient thermal performance of the proposed green roof with coarse recycled materials.

- The substrate layer's thickness was three times higher than that of coarse aggregates for the drainage layer, while its Rc-value was mostly 9\% higher. Considering an equal thickness for the aforementioned layers, the coarse aggregate layer's thermal resistance could be better than that of the unsaturated substrate layer.

- After translating green roof layers' initial hygrothermal properties into WUFI software, the thermal performance of the models with and without coarse recycled materials was reliably validated with that of roofing systems. Besides, a stable distribution of temperature through green roof models' depth was observed, similarly to what occurred for the lab-scale green roof specimens, where the difference between the modelling and experimental specimens' temperatures through the layers' depth was no more than $1.7 \%$.

- Considering a constant thickness for the substrate layer $(15 \mathrm{~cm}), 6-\mathrm{cm}$ drainage layer either with natural coarse aggregates or with recycled coarse aggregates represents the optimum design for the roofing system. The 18-cm unsaturated substrate layer with and without coarse recycled materials was considered as an optimum design for the rooftops, while a constant thickness of $5 \mathrm{~cm}$ was considered for the drainage layer.

- A simultaneous change in the substrate and drainage layers' thickness showed that 6-cm drainage layer and 18-cm unsaturated substrate layer (NCA6-SC18 and RCA6-SP18) were the best design to provide a sufficient thermal resistance for the roofing systems.

Finally, the proposed green roof models with optimized thicknesses can be recommended to be used for the green roof systems, owing to the importance of choosing lighter materials with an adequate thermal performance for the rooftops.

\section{Acknowledgement}


This research was funded through the University of Liège (ULiège) and ARC grant for Concerted Research Actions, financed by the French Community of Belgium, Wallonia-Brussels Federation (CityRoof project: Analogous green roofs for urban ecosystem services (2020-2023)).

\section{References}

[1] T. Abergel, B. Dean, J. Dulac, Towards a zero-emission, efficient, and resilient buildings and construction sector, Global Status Report. (2017).

[2] Directive, Directive 2010/31/eu of the European parliament and of the council of 19 May 2010 on the energy performance of buildings. Available from: http://www.epbd-ca.eu. Accessed 5 Mar 2013., (2010).

[3] M. Nematzadeh, A.A. Shahmansouri, M. Fakoor, Post-fire compressive strength of recycled PET aggregate concrete reinforced with steel fibers: Optimization and prediction via RSM and GEP, Construction and Building Materials. 252 (2020) 119057. https://doi.org/10.1016/j.conbuildmat.2020.119057.

[4] F. Ascione, R.F. De Masi, F. de Rossi, S. Ruggiero, G.P. Vanoli, Optimization of building envelope design for nZEBs in Mediterranean climate: Performance analysis of residential case study, Applied Energy. 183 (2016) 938-957. https://doi.org/10.1016/j.apenergy.2016.09.027.

[5] Y. Fan, X. Xia, A multi-objective optimization model for energy-efficiency building envelope retrofitting plan with rooftop PV system installation and maintenance, Applied Energy. 189 (2017) 327-335. https://doi.org/10.1016/j.apenergy.2016.12.077.

[6] S. Mirrahimi, M.F. Mohamed, L.C. Haw, N.L.N. Ibrahim, W.F.M. Yusoff, A. Aflaki, The effect of building envelope on the thermal comfort and energy saving for high-rise buildings in hot-humid climate, Renewable and Sustainable Energy Reviews. 53 (2016) 1508-1519. https://doi.org/10.1016/j.rser.2015.09.055.

[7] S.B. Sadineni, S. Madala, R.F. Boehm, Passive building energy savings: A review of building envelope components, Renewable and Sustainable Energy Reviews. 15 (2011) 3617-3631. https://doi.org/10.1016/j.rser.2011.07.014.

[8] M. Sleiman, G. Ban-Weiss, H.E. Gilbert, D. François, P. Berdahl, T.W. Kirchstetter, H. Destaillats, R. Levinson, Soiling of building envelope surfaces and its effect on solar reflectance-Part I: Analysis of roofing product databases, Solar Energy Materials and Solar Cells. $95 \quad$ (2011) 3385-3399. https://doi.org/10.1016/j.solmat.2011.08.002.

[9] J. Coma, G. Pérez, C. Solé, A. Castell, L.F. Cabeza, Thermal assessment of extensive green roofs as passive tool for energy savings in buildings, Renewable Energy. 85 (2016) 1106-1115.

[10] M. Ebadati, M.A. Ehyaei, Reduction of energy consumption in residential buildings with green roofs in three different climates of Iran, Advances in Building Energy Research. 14 (2020) 66-93. https://doi.org/10.1080/17512549.2018.1489894.

[11] M. Kazemi, M. Hajforoush, P.K. Talebi, M. Daneshfar, A. Shokrgozar, S. Jahandari, M. Saberian, J. Li, In-situ strength estimation of polypropylene fibre reinforced recycled aggregate concrete using Schmidt rebound hammer and point load test, Journal of Sustainable Cement-Based Materials. (2020) 1-18.

[12] E. Oberndorfer, J. Lundholm, B. Bass, R.R. Coffman, H. Doshi, N. Dunnett, S. Gaffin, M. Köhler, K.K. Liu, B. Rowe, Green roofs as urban ecosystems: ecological structures, functions, and services, BioScience. 57 (2007) 823-833.

[13] B. Raji, M.J. Tenpierik, A. van den Dobbelsteen, The impact of greening systems on building energy performance: A literature review, Renewable and Sustainable Energy Reviews. 45 (2015) 610-623.

[14] K. Perini, P. Rosasco, Is greening the building envelope economically sustainable? An analysis to evaluate the advantages of economy of scope of vertical greening systems and green roofs, Urban Forestry \& Urban Greening. 20 (2016) 328-337. https://doi.org/10.1016/j.ufug.2016.08.002.

[15] T. Van Renterghem, M. Hornikx, J. Forssen, D. Botteldooren, The potential of building envelope greening to achieve quietness, Building and Environment. 61 (2013) 34-44. https://doi.org/10.1016/j.buildenv.2012.12.001.

[16] S. Cascone, F. Catania, A. Gagliano, G. Sciuto, A comprehensive study on green roof performance for retrofitting existing buildings, Building and Environment. 136 (2018) 227-239.

[17] P.C. Tabares-Velasco, M. Zhao, N. Peterson, J. Srebric, R. Berghage, Validation of predictive heat and mass transfer green roof model with extensive green roof field data, Ecological Engineering. 47 (2012) 165-173.

[18] M. Kazemi, L. Courard, Simulation of humidity and temperature distribution in green roof with pozzolana as drainage layer: influence of outdoor seasonal weather conditions and internal ceiling temperature, Science and Technology for the Built Environment. 27 (2021) 509-523.

[19] M. Kazemi, L. Courard, Modelling thermal and humidity transfers within green roof systems: effect of rubber crumbs and volcanic gravel, Advances in Building Energy Research. 0 (2020) 1-26. https://doi.org/10.1080/17512549.2020.1858961.

[20] M. Sleiman, T.W. Kirchstetter, P. Berdahl, H.E. Gilbert, S. Quelen, L. Marlot, C.V. Preble, S. Chen, A. Montalbano, O. Rosseler, H. Akbari, R. Levinson, H. Destaillats, Soiling of building envelope surfaces and its 
effect on solar reflectance - Part II: Development of an accelerated aging method for roofing materials, Solar Energy Materials and Solar Cells. 122 (2014) 271-281. https://doi.org/10.1016/j.solmat.2013.11.028.

[21] S.B. Chenani, S. Lehvävirta, T. Häkkinen, Life cycle assessment of layers of green roofs, Journal of Cleaner Production. 90 (2015) 153-162.

[22] C.Y. Jim, Air-conditioning energy consumption due to green roofs with different building thermal insulation, Applied Energy. 128 (2014) 49-59.

[23] S.B. Mickovski, K. Buss, B.M. McKenzie, B. Sökmener, Laboratory study on the potential use of recycled inert construction waste material in the substrate mix for extensive green roofs, Ecological Engineering. 61 (2013) 706-714.

[24] M. Papafotiou, N. Pergialioti, L. Tassoula, I. Massas, G. Kargas, Growth of Native Aromatic Xerophytes in an Extensive Mediterranean Green Roof as Affected by Substrate Type and Depth and Irrigation Frequency, HortScience. 48 (2013) 1327-1333. https://doi.org/10.21273/HORTSCI.48.10.1327.

[25] G. Vesuviano, V. Stovin, A generic hydrological model for a green roof drainage layer, Water Science and Technology. 68 (2013) 769-775.

[26] M. Wanielista, M. Kelly, M. Hardin, A Comparative analysis of greenroof designs including depth of media, drainage layer materials, and pollution control media, Florida Department of Environmental Protection: Tallahassee, FL, USA. (2008).

[27] S. Parizotto, R. Lamberts, Investigation of green roof thermal performance in temperate climate: A case study of an experimental building in Florianópolis city, Southern Brazil, Energy and Buildings. 43 (2011) 1712-1722.

[28] S.-E. Ouldboukhitine, R. Belarbi, I. Jaffal, A. Trabelsi, Assessment of green roof thermal behavior: A coupled heat and mass transfer model, Building and Environment. 46 (2011) 2624-2631. https://doi.org/10.1016/j.buildenv.2011.06.021.

[29] M. Qin, G. Walton, R. Belarbi, F. Allard, Simulation of whole building coupled hygrothermal-airflow transfer in different climates, Energy Conversion and Management. 52 (2011) 1470-1478.

[30] D.M. Sumner, J.M. Jacobs, Utility of Penman-Monteith, Priestley-Taylor, reference evapotranspiration, and pan evaporation methods to estimate pasture evapotranspiration, Journal of Hydrology. 308 (2005) 81-104.

[31] D. Zirkelbach, Green roofs - hygrothermal simulation of moisture and energy performance, (2017) 6.

[32] S. Jahandari, Z. Tao, M. Saberian, M. Shariati, J. Li, M. Abolhasani, M. Kazemi, A. Rahmani, M. Rashidi, Geotechnical properties of lime-geogrid improved clayey subgrade under various moisture conditions, Road Materials and Pavement Design. 0 (2021) 1-19. https://doi.org/10.1080/14680629.2021.1950816.

[33] J. Yang, Z.-H. Wang, Physical parameterization and sensitivity of urban hydrological models: Application to green roof systems, Building and Environment. $75 \quad$ (2014) 250-263. https://doi.org/10.1016/j.buildenv.2014.02.006.

[34] T. Sun, E. Bou-Zeid, Z.-H. Wang, E. Zerba, G.-H. Ni, Hydrometeorological determinants of green roof performance via a vertically-resolved model for heat and water transport, Building and Environment. 60 (2013) 211-224. https://doi.org/10.1016/j.buildenv.2012.10.018.

[35] Y. He, H. Yu, N. Dong, H. Ye, Thermal and energy performance assessment of extensive green roof in summer: A case study of a lightweight building in Shanghai, Energy and Buildings. 127 (2016) 762-773. https://doi.org/10.1016/j.enbuild.2016.06.016.

[36] M. Vertal', M. Zozulák, A. Vašková, A. Korjenic, Hygrothermal initial condition for simulation process of green building construction, Energy and Buildings. 167 (2018) 166-176.

[37] C. Fabiani, J. Coma, A.L. Pisello, G. Perez, F. Cotana, L.F. Cabeza, Thermo-acoustic performance of green roof substrates in dynamic hygrothermal conditions, Energy and Buildings. 178 (2018) 140-153. https://doi.org/10.1016/j.enbuild.2018.08.024.

[38] Y. He, H. Yu, A. Ozaki, N. Dong, Thermal and energy performance of green roof and cool roof: A comparison study in Shanghai area, Journal of Cleaner Production. 267 (2020) 122205. https://doi.org/10.1016/j.jclepro.2020.122205.

[39] T. Sun, E. Bou-Zeid, G.-H. Ni, To irrigate or not to irrigate: Analysis of green roof performance via a verticallyresolved hygrothermal model, Building and Environment. 73 (2014) 127-137. https://doi.org/10.1016/j.buildenv.2013.12.004.

[40] Y. He, H. Yu, A. Ozaki, N. Dong, S. Zheng, Influence of plant and soil layer on energy balance and thermal performance of green roof system, Energy. 141 (2017) 1285-1299. https://doi.org/10.1016/j.energy.2017.08.064.

[41] J. Coma, G. Pérez, A. Castell, C. Solé, L.F. Cabeza, Green roofs as passive system for energy savings in buildings during the cooling period: use of rubber crumbs as drainage layer, Energy Efficiency. 7 (2014) 841849.

[42] B. Schafaczek, D. Zirkelbach, Ermittlung von Materialeigenschaften und effektiven Übergangsparametern von Dachbegrünungen zur zuverlässigen Simulation der hygrothermischen Verhältnisse in und unter Gründächern bei beliebigen Nutzungen und unterschiedlichen Standorten:[Abschlussbericht], Fraunhofer-IRB-Verlag, 2013.

[43] D. Zirkelbach, S.-R. Mehra, K.-P. Sedlbauer, H.-M. Künzel, B. Stöckl, A hygrothermal green roof model to simulate moisture and energy performance of building components, Energy and Buildings. 145 (2017) 79-91. 
[44] S. Cascone, Green Roof Design: State of the Art on Technology and Materials, Sustainability. 11 (2019) 3020. https://doi.org/10.3390/su11113020.

[45] H. Ling, C. Chen, H. Qin, S. Wei, J. Lin, N. Li, M. Zhang, N. Yu, Y. Li, Indicators evaluating thermal inertia performance of envelops with phase change material, Energy and Buildings. 122 (2016) 175-184. https://doi.org/10.1016/j.enbuild.2016.04.009.

[46] A. Bellazzi, B. Barozzi, M.C. Pollastro, I. Meroni, Thermal resistance of growing media for green roofs: To what extent does the absence of specific reference values potentially affect the global thermal resistance of the green roof? An experimental example, Journal of Building Engineering. 28 (2020) 101076.

[47] O. Saadatian, K. Sopian, E. Salleh, C.H. Lim, S. Riffat, E. Saadatian, A. Toudeshki, M.Y. Sulaiman, A review of energy aspects of green roofs, Renewable and Sustainable Energy Reviews. 23 (2013) 155-168.

[48] H. Akbarzadeh Bengar, A.A. Shahmansouri, N. Akkas Zangebari Sabet, K. Kabirifar, V. W.Y. Tam, Impact of elevated temperatures on the structural performance of recycled rubber concrete: Experimental and mathematical modeling, Construction and Building $\quad$ Materials. $\quad 255 \quad$ (2020) 119374. https://doi.org/10.1016/j.conbuildmat.2020.119374.

[49] M. Kazemi, R. Madandoust, J. de Brito, Compressive strength assessment of recycled aggregate concrete using Schmidt rebound hammer and core testing, Construction and Building Materials. 224 (2019) 630-638.

[50] M. Nematzadeh, J. Dashti, B. Ganjavi, Optimizing compressive behavior of concrete containing fine recycled refractory brick aggregate together with calcium aluminate cement and polyvinyl alcohol fibers exposed to acidic environment, Construction and Building Materials. $164 \quad$ (2018) 837-849. https://doi.org/10.1016/j.conbuildmat.2017.12.230.

[51] Z. Zhao, L. Courard, S. Groslambert, T. Jehin, A. Léonard, X. Jianzhuang, Use of recycled concrete aggregates from precast block for the production of new building blocks: An industrial scale study, Resources, Conservation and Recycling. 157 (2020) 104786.

[52] P. Mehrabi, M. Shariati, K. Kabirifar, M. Jarrah, H. Rasekh, N.T. Trung, A. Shariati, S. Jahandari, Effect of pumice powder and nano-clay on the strength and permeability of fiber-reinforced pervious concrete incorporating recycled concrete aggregate, Construction and Building Materials. 287 (2021) 122652. https://doi.org/10.1016/j.conbuildmat.2021.122652.

[53] A. Toghroli, P. Mehrabi, M. Shariati, N.T. Trung, S. Jahandari, H. Rasekh, Evaluating the use of recycled concrete aggregate and pozzolanic additives in fiber-reinforced pervious concrete with industrial and recycled fibers, Construction and Building Materials. 252 (2020) 118997.

[54] M. Nematzadeh, A. Baradaran-Nasiria, Mechanical performance of fiber-reinforced recycled refractory brick concrete exposed to elevated temperatures, Computers and Concrete. 24 (2019) 19-35. https://doi.org/10.12989/cac.2019.24.1.019.

[55] M. Kazemi, L. Courard, J. Hubert, Heat transfer measurement within green roof with incinerated municipal solid waste aggregates, Sustainability. 13 (2021) 7115. https://doi.org/10.3390/su13137115.

[56] ISO 9869-1, Thermal insulation, Building elements, In-situ measurement of thermal resistance and thermal transmittance-Part 1: Heat flow meter method, London: BSI. (2014).

[57] N. Simões, R. Almeida, A. Tadeu, M. Brett, J. Almeida, Comparison between cork-based and conventional green roof solutions, Building and Environment. 175 (2020) 106812. https://doi.org/10.1016/j.buildenv.2020.106812.

[58] EN 12620, Aggregates for concrete. European Committee for Standardization, ITeh Standards Store. (2013). https://standards.iteh.ai/catalog/standards/cen/aef412e6-36ce-49d3-afaa-5200d721ff84/en-12620-2013 (accessed January 19, 2021).

[59] U. Berardi, The impact of aging and environmental conditions on the effective thermal conductivity of several foam materials, Energy. 182 (2019) 777-794. https://doi.org/10.1016/j.energy.2019.06.022.

[60] C. Peng, Z. Wu, In situ measuring and evaluating the thermal resistance of building construction, Energy and Buildings, 40 (2008) 2076-2082. https://doi.org/10.1016/j.enbuild.2008.05.012.

[61] G. Desogus, S. Mura, R. Ricciu, Comparing different approaches to in situ measurement of building components thermal resistance, Energy and Buildings. 43 (2011) 2613-2620.

[62] A. Rodler, S. Guernouti, M. Musy, Bayesian inference method for in situ thermal conductivity and heat capacity identification: Comparison to ISO standard, Construction and Building Materials. 196 (2019) 574-593.

[63] ASTM D4611 - 16, Standard test method for specific heat of rock and soil, ASTM International, 2018. https://doi.org/10.1520/D4611-16.

[64] Engineering ToolBox, Specific Heat of some common Substances, (2003). https://www.engineeringtoolbox.com/specific-heat-capacity-d_391.html (accessed January 19, 2021).

[65] IES VE, Thermal Conductivity, Specific Heat Capacity and Density, (2018). https://help.iesve.com/ve2018/table_6_thermal_conductivity_specific_heat_capacity_and_density.htm (accessed January 19, 2021).

[66] ISO 16586, Soil quality - Determination of soil water content as a volume fraction on the basis of known dry bulk density - $\quad$ Gravimetric method, $\quad$ ISO. 
https://www.iso.org/cms/render/live/en/sites/isoorg/contents/data/standard/03/23/32317.html (accessed October 27, 2020).

[67] H.M. Künzel, Simultaneous heat and moisture transport in building components, One-and Two-Dimensional Calculation Using Simple Parameters. IRB-Verlag Stuttgart. 65 (1995).

[68] S.B. Awulachew, P. Lemperiere, T. Tulu, Training material on agricultural water management, International Water Management Institute; International Livestock Research Institute; Adama University, Addis Ababa, Ethiopia; Nairobi, Kenya; Adama, Ethiopia, 2009.

[69] C. Brouwer, A. Goffeau, M. Heibloem, Irrigation water management: training manual no. 1-introduction to irrigation, Food and Agriculture Organization of the United Nations, Rome, Italy. (1985) 102-103.

[70] R. Madandoust, M. Kazemi, P.K. Talebi, J. de Brito, Effect of the curing type on the mechanical properties of lightweight concrete with polypropylene and steel fibres, Construction and Building Materials. 223 (2019) 10381052.

[71] M. Krus, Moisture transport and storage coefficients of porous mineral building materials: Theoretical principles and new test methods, Fraunhofer IRB Verlag Stuttgart, 1996.

[72] DIN 52 615, Determination of water vapour (moisture) permeability of construction and insulating materials., 1973.

[73] R. Schirmer, Die Diffusionszahl von Wasserdampf-Luft-Gemischen und die Verdampfungsgeschwindigkeit, PhD Thesis, VDI-Verlag, 1938.

[74] T. Togkalidou, M. Karoglou, A. Bakolas, A. Giakoumaki, A. Moropoulou, Correlation of water vapor permeability with microstructure characteristics of building materials using robust chemometrics, Transport in Porous Media. 99 (2013) 273-295.

[75] ISO 12572, Hygrothermal performance of building materials and products - Determination of water vapour transmission properties, (2001). https://www.iso.org/obp/ui/\#iso:std:iso:12572:ed-1:v1:en (accessed November 1, 2020).

[76] EN 1015-19, Methods of test for mortar for masonry. Determination of water vapour permeability of hardened rendering and plastering mortars, (1999).

[77] BS 5250, Code of practice for control of condensation in buildings, British Standards Institution. (2011).

[78] H. Cagnon, J.E. Aubert, M. Coutand, C. Magniont, Hygrothermal properties of earth bricks, Energy and Buildings. 80 (2014) 208-217. https://doi.org/10.1016/j.enbuild.2014.05.024.

[79] G. Giada, R. Caponetto, F. Nocera, Hygrothermal Properties of Raw Earth Materials: A Literature Review, Sustainability. 11 (2019) 5342. https://doi.org/10.3390/su11195342.

[80] EN 1925, Natural stone test methods. Determination of water absorption coefficient by capillarity, (1999). https://shop.bsigroup.com/ProductDetail?pid=000000000019973432 (accessed December 10, 2020).

[81] L. Soudani, A. Fabbri, M. Woloszyn, A.-C. Grillet, J.-C. Morel, Hydric characterisation of rammed earth samples for different lime concentrations, in: IOP Conference Series: Earth and Environmental Science, IOP Publishing, 2018: p. 012010.

[82] A. Holm, M. Krus, H.M. Künzel, Feuchtetransport über Materialgrenzen im Mauerwerk/Moisture transport through interfaces in masonry, Restoration of Buildings and Monuments. 2 (1996) 375-396.

[83] J.M. Pérez-Bella, J. Domínguez-Hernández, E. Cano-Suñén, J.J. del Coz-Díaz, F.P. Álvarez Rabanal, A correction factor to approximate the design thermal conductivity of building materials. Application to Spanish façades, Energy and Buildings. 88 (2015) 153-164. https://doi.org/10.1016/j.enbuild.2014.12.005.

[84] F. Ochs, W. Heidemann, H. Müller-Steinhagen, Effective thermal conductivity of moistened insulation materials as a function of temperature, International Journal of Heat and Mass Transfer. 51 (2008) 539-552.

[85] D. Allinson, M. Hall, Hygrothermal analysis of a stabilised rammed earth test building in the UK, Energy and Buildings. 42 (2010) 845-852. https://doi.org/10.1016/j.enbuild.2009.12.005.

[86] L. Veas, Development and application of a methodological model that allows evaluate and compare the behaviour of external walls exposed to moisture phenomenons, PhD Thesis, UCL., 2006.

[87] M. Krus, H.M. Künzel, Flüssigtransport im Übersättigungsbereich, Fraunhofer-Institut für Bauphysik, 1995.

[88] M.I.M. Torres, V.P. de Freitas, Modelling of rising damp in historical buildings, (2001) 381-390.

[89] S. Kordziel, S.V. Glass, C.R. Boardman, R.A. Munson, S.L. Zelinka, S. Pei, P.C. Tabares-Velasco, Hygrothermal characterization and modeling of cross-laminated timber in the building envelope, Building and Environment. 177 (2020) 106866. https://doi.org/10.1016/j.buildenv.2020.106866.

[90] A. Pianella, R.E. Clarke, N.S.G. Williams, Z. Chen, L. Aye, Steady-state and transient thermal measurements of green roof substrates, Energy and Buildings. 131 (2016) 123-131. https://doi.org/10.1016/j.enbuild.2016.09.024.

[91] D.J. Sailor, M. Hagos, An updated and expanded set of thermal property data for green roof growing media, Energy and Buildings. 43 (2011) 2298-2303. https://doi.org/10.1016/j.enbuild.2011.05.014.

[92] F. Hu, S. Wu, Y. Sun, Hollow-Structured Materials for Thermal Insulation, Advanced Materials. 31 (2019) 1801001 .

[93] B.M. Suleiman, J. Larfeldt, B. Leckner, M. Gustavsson, Thermal conductivity and diffusivity of wood, Wood Science and Technology. 33 (1999) 465-473. 
[94] X. Zhou, F. Zheng, H. Li, C. Lu, An environment-friendly thermal insulation material from cotton stalk fibers, Energy and Buildings. 42 (2010) 1070-1074. https://doi.org/10.1016/j.enbuild.2010.01.020.

[95] Y. Yang, C.I. Davidson, J. Zhang, Evaluation Of Thermal Performance Of Green Roofs Via Field Measurements And Hygrothermal Simulations, Energy and Buildings. (2021) 110800.

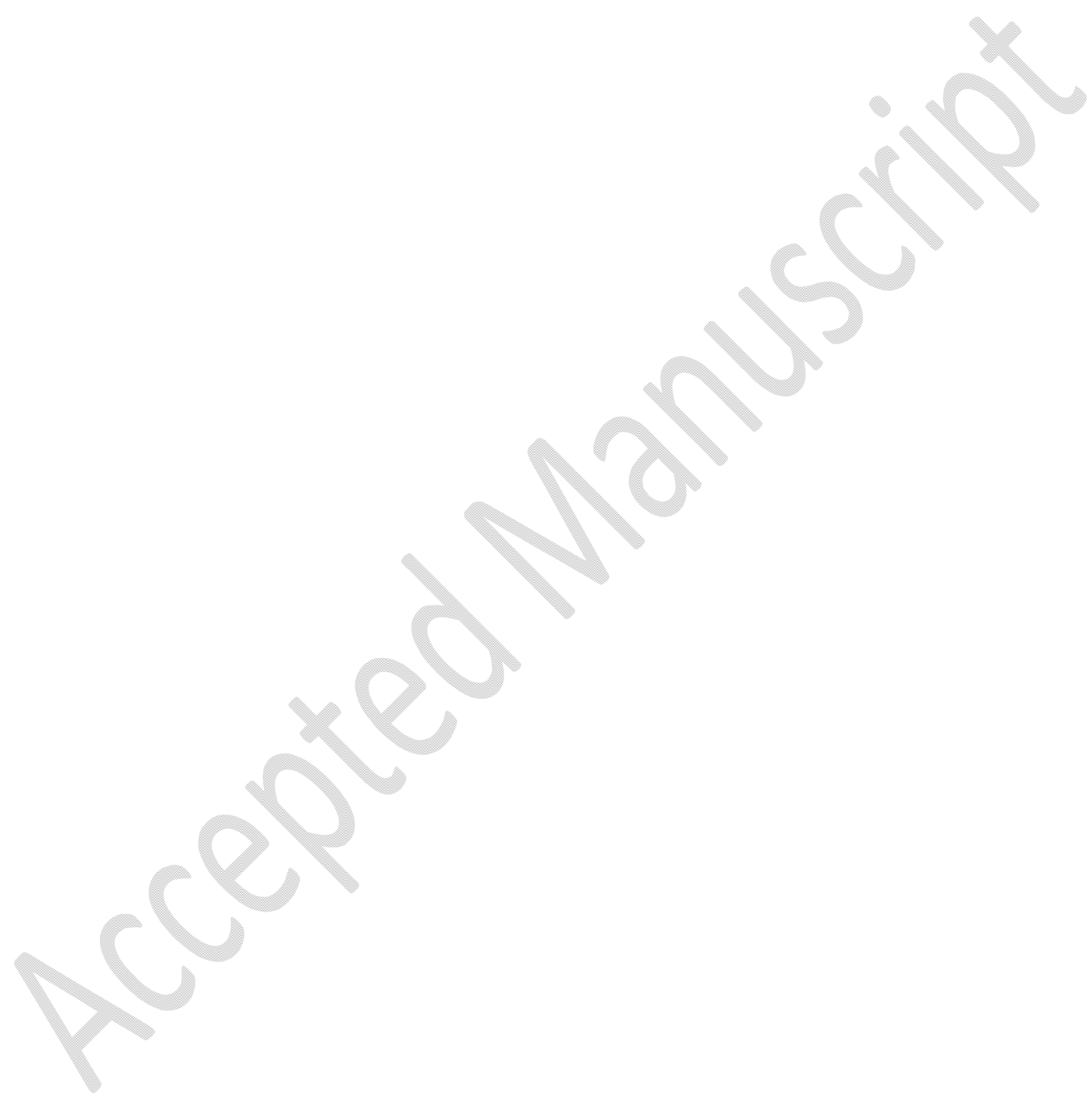

